\title{
Survivability: Vasubandhu and Sanghabhadra on the Continuity of the Life of a Sentient Being as Translated by Xuanzang
}

\author{
ERNEST BILLINGS (BILLY) BREWSTER \\ Iona College, New Rochelle, New York \\ ebrewster@iona.edu
}

Abstract: This paper presents the doctrinal argumentation on the continuity of the life of an individual sentient being found in the Abhidharma Buddhist texts translated by Xuanzang and his Tang Dynasty (618-907) collaborators. Vasubandhu, in the Treasury of the Abhidharma, and Sanghabhadra, in his two commentaries on this text, the Abbidharma Treatise Conforming to the Correct Logic, and the Treatise Clarifying Abbidharma Tenets, enlist the doctrines of the continuum (Skt. samtanna; Ch. xiangxu 相續) and the aggregates (Skt. skandha; Ch. yun 蘊) to support the idea that the life of an individual sentient being does not end with the death of the body. The conceptualization of survivability, articulated by Vasubandhu and Sanghabhadra in these three Abhidharma masterworks, is that an individual sentient being continues in life, and survives death, the afterlife, and reincarnation, in the form of aggregates bundled together in the continuum. This paper enlists a source criticism methodology to compare the translations of the Abbidharma texts by Xuanzang and his coterie, with earlier recensions of the texts in Chinese, and received versions in Tibetan and Sanskrit, to describe the definitions, examples, and logic employed by Vasubandhu and Sanghabhadra in their argumentation in defense of the doctrine that the life of an individual sentient being persists throughout the four stages of the Buddhist life cycle: life, death, the afterlife, and reincarnation. Ultimately, for Vasubandhu and Sanghabhadra, as well as 
for Xuanzang, the individual life constituted by the continuum of a sentient being persists in the face of constant change and radical impermanence.

Keywords: Xuanzang, Vasubandhu, Sanghabhadra, Abhidharmanyānanusāra sástra, Apidamo shun zhengli lun, 阿毘達 磨順正理論, *Abhidharmasamayapradīpikà śāstra, Apidamo zang xianzonglun, 阿毘達磨藏顯宗論

DOI: https://dx.doi.org/10.15239/hijbs.03.01.06

\section{Introduction}

Tn their doctrinal works composed during the fifth century, the Indian philosopher, Vasubandhu (fl. fifth century C.E.), and his prolific commentator and rival, Sanghabhadra (fl. fifth century C.E.), address questions posed by Brāhmanical and Buddhist theorists regarding the survivability, or the continuity, of the life of a sentient being. How does a sentient being maintain continuity in a changing material world? What qualities of a sentient being survive death, transmigration, and reincarnation? In the face of constant change in the Buddhist cycle of death and rebirth, what aspects of a sentient being survive, if not an àtman, or a self? In their efforts to uphold the Buddhist tenets of impermanence and no-self in their doctrinal masterworks, Vasubandhu and Sanghabhadra engage in thematic questions regarding the survivability of a sentient being through four stages of the Buddhist life cycle: life, dying, the afterlife, and reincarnation.

Two centuries after Vasubandhu and Sanghabhadra, Xuanzang 玄 牀 (602?-664 C.E.), the intrepid Silk Road traveler, scholar-monk, and polymath, with a team of researchers and scribes, undertakes a massive translation and exegesis of the Indic Brāhmanical and Buddhist texts on dying, death, transmigration, and reincarnation. While ensconced in a capacious and Imperially-financed translation studio 
in the capital City of Chang'an during the early years of the Tang dynasty (618-907 C.E.), Xuanzang and a legion of exegetes translate the works of the Indic Buddhist thinkers Vasubandhu and Sanghabhadra from Sanskrit into Chinese. During this effort they render a comprehensive translation of the Treasury of the Abhidharma by Vasubandhu, into thirty fascicle rolls, ${ }^{1}$ and two lengthy translations of the criticism and exegesis on the Treasury of the Abhidharma, composed by Sanghabhadra: the Abhidharma Treatise Conforming to the Correct Logic (Skt. Abhidharmanyānanusāra śāstra; Ch. Apidamo shun zhengli lun 阿毘達磨順正理論 $)^{2}$ into sixty fascicle rolls, and the Treatise Clarifying Abhidharma Tenets (Skt. *Abhidharmasamayapradīpikā śástra; Ch. Apidamo zang xianzong lun 阿毘達磨藏 顯宗論 $)^{3}$ into forty fascicle rolls.

In the process of translating the treatises of Vasubandhu and Sanghabhadra, Xuanzang and his team of exegetes examine the Abhidharma doctrine of survivability, the capacity of a sentient being to withstand the states of living, dying, transmigration, and rebirth. In their exegeses of the scriptures, Xuanzang and his coterie locate the doctrinal evidence and argumentation for the Abhidharma Buddhist explanation of survivability: how a sentient being survives the changing conditions of the material world, the dissolution and loss of the corporeal body, the process of transmigration into the afterlife, and reincarnation into a new living form. In the Treasury of the Abhidharma, and in the two commentarial works on this text, Vasubandhu and Sanghabhadra enlist the Buddhist theory of the skandhas to conceptualize the survivability of a sentient being.

1 Abhidharmakośa-bhāsya, Apidamo jushe lun, T no. 1558, 29. Translated between June 3rd, 651 C.E. and September 13th, 654 C.E. at his translation studio (Ch. Fanjing yuan 翻經院) in the Great Compassion Temple (Da Ci'en si 大慈恩寺) in Chang’an. For dating, see chronology in appendix of Lusthaus, Buddhist Phenomenology, 565.

2 Apidamo shun zhengli lun, $T$ no. 1562, 29. Translated between 653 C.E. and 654 C.E.

3 Apidamo zang xianzong lun, T no. 1563, 29. Translated between April 30, 651 C.E. and November 26, 652 C.E. 
They present examples and logical arguments to defend the idea that a sentient being withstands the continuous developmental changes of life, survives the demise of the corporeal body, continues into the afterlife, and is reincarnated, in the form of skandhas carried by samtanna. This study investigates the explanations, articulated by Vasubandhu and Sanghabhadra in three doctrinal masterworks, for how a sentient being maintains continuity, or survives, the four stages of the Abhidharma Buddhist life cycle. These stages include the previous life (Skt. purvabhava; Ch. benyou 本有), ${ }^{4}$ the time of becoming deceased (Skt. maranabhava; Ch. siyou 死有), the afterlife or intermediate state (Skt. antaräbhava; Ch. zhongyou 中有), ${ }^{5}$ and the time of reincarnation (Skt. upapattibhava; Ch. shengyou 生有).

Employing a source criticism research methodology, this study compares the arguments for survivability within the four stages of the Buddhist life cycle, preserved in the seventh-century Chinese translations of the Treasury of Abbidharma, the Abbidbarma Treatise Conforming to the Correct Logic, and the Treatise Clarifying Abhidharma Tenets, by Xuanzang and his team of exegetes and scribes, with the received versions of the same texts in Sanskrit and Tibetan. Versions of the Treasury of the Abhidharma exist in Sanskrit, in Tibetan, and in Chinese translations from the sixth century. The full commentarial works by Sanghabhadra, however, are extant only within the Chinese translation corpus of Xuanzang. While a work that has been catalogued as a Tibetan translation of Treatise

4 The Sanskrit word pürvabhava means 'previous existence'. The Abhidharma Buddhist analysis starts with life in the previous existence and takes purvabhava as the time of living in a corporeal body. Xuanzang's translation of the Sanskrit terminology pürvabhava means literally, 'fundamental existence' and clearly indicates the time of living. From the perspective of the next life, the pürvabhava is the previous existence in a corporeal body.

5 See Brian Cuevas's article on the subject of antaräbhava: 'Predecessors and prototypes', 263. The first sentence of his paper provides a succinct gloss on the hotly debated term: 'The Buddhist Sanskrit term antarābhava refers quite literally to existence (bhāva) in an interval (antarāa) and designates the temporal space between death and subsequent rebirth'. 
Clarifying Abbidharma Tenets by Sanghabhadra exists in the Derge canon (D no. 4091, 141), Mejor ${ }^{6}$ found that it appears to be 'a simple abridgement of the Abhidharmakosa, without polemics'. Because the original doctrinal discussions on the topic of survivability by Sanghabhadra survive only in the Chinese renditions put together by Xuanzang and his team, these discussions are deserving of close examination. This paper counterbalances Sanghabhadra's doctrinal discussions with those presented by Vasubandhu, as the two authors developed their respective doctrinal stances in continuous dialogue with one another.

This research builds upon prior scholarship on the Abhidharma Buddhist conceptualization of the continuity and survival of the sentient being in terms of the skandhas and samtāna. Von Rospatt uses a doctrinal historical approach to describe how Vasubandhu employs the theory of the samtana to explain how a sentient being maintains continuity, while undergoing growth and development, in the absence of an unchanging core, self, or atman. Watson describes how Vasubandhu enlists the theory of the samtana in his explication of how a sentient being survives death and persists into the afterlife without a self, soul, or atman. ${ }^{8}$ Located within this body of scholarship, this paper describes the definitions, examples, and logic employed by Vasubandhu and Sanghabhadra, and preserved in Chinese translations by Xuanzang and his collaborators, to formulate the survival of the sentient being in terms of the samtanna and the skandhas.

6 See Mejor, Vasubandhu's Abhidharmakos'a and the Commentaries, 37. Mejor identifies this commentary, found in the Derge Tengyur canon as the *Abhidharmakośa-vṛtti sūtrānurūpā [-nàma], based upon correspondences with a fragmentary Tibetan manuscript from Dunhuang (Stein No. 591). Mejor (Vasubandhu's Abhidharmakos'a and the Commentaries, 36) thus summarizes the contents of D no. 4091, 141: 'It seems that we have here an example of an old, anonymous translation of an Indian text of a sástra-commnetary type, very early incorporated into the Tanjur and not subject to further revision or correction'.

7 Von Rospatt, The Buddhist Doctrine of Momentariness.

8 Watson, The Self's Awareness of Itself. 


\section{Momentariness, Impermanence, Samtāna, and the Five Skandhas}

The Buddhist doctrine of momentariness (Skt. kșanabhanga; Ch. cha'na mie 刹那滅), as developed in Abhidharma philosophy, postulates that every conditioned dharma (Skt. samskrta-dharma; Ch. youwei fa 有爲法) or factor comes to cease immediately upon arising. ${ }^{9}$ Each and every factor is conditioned by a myriad of causes and conditions (Skt. hetu-pratyaya; Ch. yinyuan 因緣) that precede its coming into being (Skt. bbāva; Ch. you 有, xing 性, $t i$ 體). ${ }^{10}$ All conditioned factors are impermanent (Skt. anitya; Ch. wuchang 無常) by nature. As one conditioned factor arises, it gives rise to the next, and then immediately perishes. The continuum, or the samtanna, as defined in the Abhidharma texts, is the series of discrete events that links one moment to the next in an uninterrupted flow. The theory of samtāna explains, for example, why a time-lapse video of the seed of a plant sprouting, emerging from the earth, and then flowering, appears to the viewer as the continuous movement of a singular entity. For the Abhidharma theorists, the concept of samtāna provides an explanation for the continuity of an entity or a living thing, that also embraces the Buddhist notions of momentariness and the impermanence of being.

The earliest recorded teachings of the Buddha, found in the Agamas, describe the sentient being as comprised of five skandhas, or aggregates, that arise, abide, and cease from one moment to the next. The doctrine of no-self (Skt. anātman; Ch. wuwo 無我), also attested in the Agamas, asserts that there is no singular or permanent

9 See Siderits, Buddhism as Philosophy, 119-23, for a discussion of some of the Abhidharma arguments intending to 'prove' the doctrine of momentariness.

10 Xuanzang frequently translates the Sanskrit word bhāva, meaning 'being', using the Chinese character xing 性, meaning 'nature', or $t i$ 體, meaning 'body'. See Hirakawa, Dictionary, 14 for one of numerous examples of the former and Hirakawa, Dictionary, 17, for an example of the latter. Xing also renders svabbāva, meaning something's abiding 'own-being' or 'intrinsic nature', as in zixing 自性. Another word for svabhāva is ziti 自體, meaning something's body—see Hirakawa, Dictionary, 84. 
self to be found either inside, or outside, of the five skandhas. The five skandhas constitute the physical and mental existence of the sentient being and are comprised of one corporeal or bodily form (Skt. rūpa; Ch. se 色) and four mental or psychological states: feeling and sensation (Skt. vedanā; Ch. shou 受), perception (Skt. sanjjĩ $\bar{a}$; Ch. xiang 想), mental formations (Skt. samskāra; Ch. xing 行), and consciousness (Skt. vijñana; Ch. shi 識). Watson, in describing the Buddhist positions on momentariness and impermanence that are implicit in the theory of the skandhas writes: 'for Buddhism, we are not one thing but an association of five: a bodily state and four mental states'. ${ }^{11} \mathrm{He}$ adds: 'what we are in one moment is not what we are the next'. According to the Buddhist doctrine of momentariness, the continuous, moment-to-moment evanescence and dissolution of the five skandhas in the samtāna creates the continuity of the physi$\mathrm{cal}$ and mental existence of a sentient being.

In their translations of the works of Vasubandhu and Sanghabhadra, Xuanzang and his collaborators render the Abhidharma Buddhist description of the survival of a sentient being throughout the cycle of living, death, the intermediate state, and reincarnation, in terms of the skandhas and samtāna. Sanghabhadra and Vasubandhu posit that a sentient being endures in life, survives in death, perseveres in the afterlife, and is reincarnated in a continuous samtana of the skandhas, rather than in the form of a permanent or perduring self, soul, or atman. On the position held by Vasubandhu on the five skandhas and rebirth, Stone writes:

Vasubandhu, who theorized the notion of interim being in explaining how the rebirth process continues in the absence of an unchanging soul or self, made quite clear that the intermediate being is decidedly not an ātman but a temporary karmically conditioned collection of the five aggregates (five skandhas). ${ }^{12}$

Essentially what survives death is not a unitary, permanent self,

11 Watson, 'The Self as a Dynamic Constant', 175.

12 Stone, Right Thoughts at the Last Moment, 12. 
but rather a continuum made up of multiple, impermanent aggregates that once having arisen, are constantly abiding, changing, and ceasing during each present moment in time. ${ }^{13}$

In the Abhidharma depiction of survival in the Buddhist cycle of life, immediately following corporeal death, the four psychological skandhas of a deceased sentient being are carried in the samtanna from the previous life, into an intermediate state, and then reincarnated into another life form. The psychological aspects of a sentient being, such as dispositions, memories, and states of consciousness, survive the death of the body, transmigration, and reincarnation bundled within the samtana of the four skandhas. While the corporeal body is discarded at death, the mental constituents of a sentient being thus endure in the skandhas throughout life cycle of living, death, the intermediate state, and reincarnation. Hewing closely to the Abhidharma Buddhist doctrine, Vasubandhu and Sanghabhadra posit that the mental elements of a sentient being survive in the skandhas without a permanent self, soul, or atman. The conceptualization of the survivability of a sentient being, in the treatises of Vasubandhu and Sanghabhadra, and preserved in the translations by

13 The editors of the ${ }^{*}$ Mahāvibhāșa, the foundational compendium of the Vaibhāṣika tradition of Sarvāstivāda Buddhism, appear to maintain that a discrete entity or dharma undergoes four discrete stages (Skt. avasthā; Ch. fenwei 分位) during a present moment in time (see $T$ no. 1545, 27: 39.200a9 and Cox, Disputed Dharmas, 96 for translation and analysis). These four stages are: arising (Skt. jāti, upapatti; Ch. sheng 生), abiding (Skt. sthiti; Ch. zhu 住), change (Skt. anyatā; Ch. yi 異; literally, 'becoming otherwise'), and cessation (Skt. vyaya; Ch. mie 滅). However, it is important to point out that for Sanghabhadra, the initial action of arising, the gathering up of causal power by the entity, takes place during the future $\left(\mathrm{T}^{\circ}\right)$, such that by the outset of a present moment $\left(\mathrm{T}^{1}\right)$, the entity has already arisen, before it abides, changes, and ceases in rapid succession during the course of a present moment in time. This is noted by Cox, Disputed Dharmas, 150. Sarvāstivāda Abhidharma thinkers envision of a moment as consisting in a finite temporal duration equal to 0.01333 of a second. Thus, for Sarvāstivāda theorists, a single moment is divisible into discrete stages. See Sanderson, 'Sarvāstivāda and its Critics', 42. 
Xuanzang and his collaborators, thereby demonstrates an adherence to the Buddhist concepts of momentariness, impermanence, and no-self.

\section{Surviving the Purvabhava, the World of Fundamental Being}

In the doctrinal treatises translated into Chinese by Xuanzang and his Tang cohort, Vasubandhu and Sanghabhadra posit the survival of the sentient being in the material world, the purvabhava, as contingent upon the continuous being of the skandhas. Drawing deeply from the Sarvāstivāda Abhidharma traditions of Buddhism, Vasubandhu and Sanghabhadra defend the position that the sentient being is comprised of momentary physical and mental states that are manifested by one corporeal (Skt. rüpaskandha), and four psychological skandhas collected together in samtana. To Vasubandhu and Sanghabhadra, the theory of the skandhas in samtāna provides an explanation for how a sentient being survives in an impermanent and inconstant material world. The theory of the momentariness and impermanence of the skandhas is congruent to the Buddhist assertion that physical and mental events are not metaphysically real.

In his study of the Buddhist explanations of continuity, Garfield responds to the question of why objects, and sentient beings, appear continuous and enduring in the face of constant change. He offers the Buddhist theory of the continuum of momentary events to explain the apparent continuity of an entity, a living thing, or a sentient being, over time. Garfield writes:

Given the obvious utility of discursive and other practices that take identity over time for granted, not only of persons, but of all middle-sized dry goods around us; and among these discursive practices are specifically Buddhist discourse about personal development, about the composite nature of entities, and even about gross impermanence, we need some account of why we can talk about continuants in our world. The Buddhist reply to this demand is to argue that what we usually take to be things that endure over time are in fact continua of momentary, causally interacting events. ${ }^{14}$ 
According to the theory of momentariness, the five skandhas of a sentient being arise, and then cease in one place, and then, arise and cease again, in a neighbouring location. This gives the appearance of a sentient being moving, as a unitary and continuous entity, from one place to another. In his description of this phenomenon, Watson writes:

During life, each moment of consciousness (which is one of the four kinds of mental constituents of a person) is linked to the next moment of consciousness in that it causes it to arise. The same goes for the other three kinds of mental constituent, and the physical constituent. $^{15}$

To Vasubandhu and Sanghabhadra, the linking of the momentary evanescence and dissolution of the skandhas, through the continuity of samtana, provides the explanation for how the physical and psychological aspects of a sentient being appear continuous or enduring in the purvabhava.

\section{Continuity in the Pürvabhava: Causal Efficacy, Causal Capacity, and Momentariness}

In their doctrinal works, Vasubandhu and Sanghabhadra link the Abhidharma theories of causal efficacy (Skt. käritra; Ch. zuoyong 作 用), the present energy of an entity, or dharma, and causal capability (Skt. sāmarthya; Ch. gongneng 功能), the potential energy of dharma over time, in their explanations for how a living entity maintains continuity in the pürvabhava while undergoing development and change. ${ }^{16}$ The actions, or karma, that are performed in the past, pres-

\footnotetext{
14 Garfield, Engaging Buddhism, 45.

15 Watson, 'The Self as a Dynamic Constant', 76.

16 Xuanzang's translation of Sañghabhadra's Nyāyanusāra śāstra (Apidamo shun zhengli lun, T no. 1562, 29: 52.631c5-11) explains the difference between causal efficacy (Skt. kāritra) and causal capability (Skt. sāmarthya) by adducing the example of a pair of eyes in the dark being unable to detect an object shrouded in
} 
ent, and future by a dharma are determined by both causal efficacy and causal capability. Causal efficacy applies to an action taken by a dharma in the present moment, while causal capacity applies to actions taken in either the past, or the future, of a dharma. Vasubandhu and Sanghabhadra fundamentally agree that while causal efficacy and causal capability are distinctly different, together they comprise the essence of a dharma (Ch. fati 法體). ${ }^{17}$ For example, Vasubandhu and Sanghabhadra posit that the seed of a plant contains the causal efficacy to produce a sprout but does not possess the causal efficacy

darkness. In the case of the pair of eyes in the dark room, it is due to the darkness impeding the inherent causal capability of the eyes to see things that the object shrouded in darkness remains unseen. Sanghabhadra emphasizes that the situation of being unable to detect the object when the eyes are within a dark room is not due to the darkness impeding the exercise of causal efficacy necessary to detect the object. In order for an able-bodied pair of eyes to detect an object in a dark room, the causal efficacy in the eyes must be sufficient to draw forth an effect even under the conditions of darkness. Sanghabhadra writes: 'there are two kinds of power (Skt. śakti) in conditioned factors: firstly, causal efficacy; and secondly, causal capability. Causal efficacy denotes the causal capacity to draw forth an effect. But it is not the case that causal efficacy can be completely subsumed under causal capability. And causal capability is distinct from causal efficacy. For example, the capability of seeing something is impeded by darkness when the eye is within darkness. What is impeded is not the causal efficacy. That is to say that the impediment of darkness impedes the capability to see things. For this reason, when the eye in the darkness is able to draw forth the effect (of seeing an object), it means that in the present position the causal efficacy is not lacking'. 諸法勢力 總有二種: 一、名作用; 二、謂功能. 引果功能, 名為作用. 非唯作用, 總攝功能, 功 能異於作用. 且闇中眼見色功, 能為闇所違, 非違作用. 謂有闇障, 違見功能. 故眼 闇中, 不能見色. 引果作用, 非闇所違. 故眼闇中, 亦能引果. 無現在位, 作用有閶. See analysis of this passage in Cox, Disputed Dharmas, 142-3; also see Frauwallner, Studies in Abbidharma, 201.

17 Cox, Disputed Dharmas, 143: 'Sanghabhadra's assertion that factors in the past and future have only intrinsic nature (svabhāva) is intended to suggest simply that they do not have activity, which characterizes factors only when they are present'. 
to produce a flower in the present moment. The seed, however, does possess the causal capability to engender the flower at a future time and place.

Vasubandhu determines the Brāhmanical interpretation of causal efficacy, in terms of a static and permanent essence that ensures the identity of a living entity through change, to be incongruent with the Buddhist doctrine of the impermanence of all conditioned factors. According to the Abhidharma theorists, the intrinsic nature (Skt. svabhāva; Ch. zixing 自性) of a conditioned factor, has a causal efficacy that is exercised in one location, and at one point in time, within a living continuum. Sanghabhadra elaborates on the momentary essence of conditioned factors in the Abhidharma Treatise Conforming to the Correct Logic. He writes:

The individual essences of the dharmas exist in a perpetual series, although they are not permanent by nature, as they undergo transformation.

法體恒有, 而非是常性變異故. ${ }^{18}$

The Abhidharma theorists posit that the causal efficacy of a dharma provides the energy that enables an insentient or sentient entity to initiate an activity. The causal efficacy within a dharma initiates a sequence of causally interacting momentary events; each event is empowered by a causal capacity that is specific to a dharma. Together, the causal efficacy and the causal capacity within a dharma generate a series of linked moment-to-moment actions that form a continuum or samtana. The continuum of linked momentary actions of the dharmas creates the appearance of the singular unity of an entity as it undergoes continuous material change in the purvabbava, the world of fundamental being.

In the Treasury of Abbidharma, Vasubandhu adduces the example of a seed maturing into a fully-leafed plant to demonstrate how a living entity retains continuity during the material transformations

18 Nyāyanusāra śāstra, Apidamo shun zhengli lun, T no. 1562, 29: 52.633.c26. 
that occur during growth and development. Vasubandhu begins by positing that the seed of a plant contains the causal capacity, or the generative energy, to initiate the production of the sprouts and leaves of the plant. In fascicle ten of chapter three of the Treasury of Abbidharma, Vasubandhu states:

The sprout and leaves, etc., [of a plant] are generated from the seed.

從種子芽葉等生. ${ }^{19}$

Vasubandhu avers that the process of growth of the plant is initiated by the causal efficacy that is embedded within the seed. As the plant matures, each material alteration in the development in the plant is engendered by a specific causal capacity within the continuum of the plant. ${ }^{20}$ For example, the causal capacity that stimulates the germi-

19 Abhidharmakośa-bhāṣya, Apidamo jushe lun, T no. 1558, 29: $10.54 \mathrm{c} 01$.

20 Nyāyanusāra śāstra, Apidamo shun zhengli lun, $T$ no. 1562, 29: 51.629c18-630a6: 'The seed and the sprout, etc., form a single continuum (Skt: samtana). Since the flower has the causal capacity of the seed, the sprout also has the causal capacity of flowering. There is no difference between their causal capabilities. There is no separate entity of the flower from these causal capacities. Since the flower contains the causal capacity [of being able to draw forth the fruit], the flower provides the contributory conditions that engender the fruit. It is in this very way that the sprout, etc., grow. However, at that time, the flower only engenders the fruit, and not the sprout, etc.' 又種芽等是一相續. 既執花有 種子功能. 芽等功能, 花亦應有. 此彼差別不可得故. 是則芽等、及種功能. 一切與 花, 無別體故. 既從花內所有功能, 花為助緣, 能生於果. 即由此故, 芽等應生. 然 於爾時, 唯能生果, 不生芽等.

But for what reason is there a not minute part of the seed that resides within the flower and has causal capacity [to be able to draw forth a fruit]? It is because at that time [that the flower and sprout has arisen], it is only that which a seed can draw forth. The flower provides the contributory conditions that draw forth and engender the fruit. A sprout, etc., is not something that a flower can draw forth'. 此有何因非於花中，可有細分種等所引功能別居? 由此爾時唯種所引. 花 為緣助能引果生. 非於花中芽等所引. 
nation of the seed initiates a series of causally-linked events that are empowered by the causal capacities that promote the generation of the sprout, the emergence of the stalk, the leafing of the plant, and the bearing of the flower and the fruit. Vasubandhu elaborates upon the specific stages in the continuum of the plant bearing fruit in the discussions located in fascicle thirty of chapter nine of the Treasury of Abbidharma. He writes:

The ordinary folk in the world say that the fruit arises from the seed, but the fruit does not follow immediately from the seed, which has already ceased when it (i.e., the fruit) arises. Nor does the fruit arise from the seed without an intervening period of time. But if that is the case, then where does the fruit come from? The fruit arises from the specific transformations of the continuum of the seed-that is to say, it (i.e., the fruit) arises from the sequence of the sprout, the stalk, and the fully-leafed plant. The fruit is ultimately engendered by the flower. But in that case, why do they (the ordinary folk) say that the fruit arises from the seed? They say this since the operations of the sprout draw upon the causal capability (Skt. sammarthya) of the flower to engender the fruit.

世間說果從種生, 然果不隨, 已壤種起. 亦非從種無間即生. 若爾從 何? 從種相續轉變差別果方得生，謂種次生芽荎葉等. 花為最後方 引果生. 若爾, 何言從種生果? 由種展轉引起花中生果功能故作是 說..$^{21}$

In the above passage, Vasubandhu relies upon the distinction between causal efficacy and causal capacity to explain the bearing of the fruit of a plant in terms of a continuum of discrete and separate events that begin with the existence of a seed. In the picture laid out by Vasubandhu and Sanghabhadra, the causal capacity of the seed determines the future causal efficacies to be exerted in subsequent

21 Abhidharmakośa-bhāṣya, Apidamo jushe lun, T no. 1558, 29: 30.158c25159a01. For corresponding Sanskrit text, see Pradhan, Abhidharmakosa-bhasya, 176. 
moments during the life of the plant. As one moment comes into being and then dissolves, another moment comes into being and ends, thus creating an uninterrupted chain of causally-linked events that form the continuum of the fruit bearing plant.

In stanza eleven of chapter three of the Treasury of Abbidharma, Vasubandhu notes that the dharmas composing the seed and the sprout occupy successive locations in space. He writes:

The continuum of the rice kernel (Skt. vrìhi), etc., arises and continues in successive places without interruption. ${ }^{22}$

如穀等相續, 處無間續生. 23

In this example Vasubandhu avers that while the germination of the seed and the emergence of the sprout belong to the single living continuum of the plant, they are qualitatively distinct events, both temporally and spatially. Moment-to-moment temporal and spatial disruptions occur as the causal bases, the causal efficacy and capacity, in the seed potentiate the emergence, abiding, and cessation of the stages of the life of the plant. These momentary events comprise the samtanna of the seed that gives the appearance of the single entity of the plant continuing through time and space.

\section{Continuity in the Purvabhava: Material replacement and impermanence}

In the Treasury of Abbidharma, Vasubandhu takes the example of the seed transforming into a plant to demonstrate that even as the

22 de la Vallée Poussin, trans., L'Abhidharmakośa de Vasubandbu, 33: 'Ètant semblable à la série du riz, l'existence ne se reproduit pas postèrieurement après avoir été interrompue'. The corresponding Sanskrit based upon Pradhan, Abhidharmakośa, 120, reads: vrīhisantāna-sādharmyād-avicchinna-bhavaudbhavah \| (AK 3.11).

23 Abbidharmakośa-bhāsya, Apidamo jushe lun, T no. 1558, 29: 8.44b18. 
causal efficacy within the seed engenders the parts of the seed to mature, decay, and ultimately, to be cast aside, the causal capacity in the seed survives in the plant. Through the processes of germination and the sprouting of the seedling, the seed undergoes a gradual replacement of its parts. While the seed is materially transformed through the process of growth and development, it perdures nonetheless. According to the Abhidharma principle of material replacement, the seed, while transformed into a fledgling sprout, survives the process of change. As the constituent parts of the plant are gradually transformed and replaced, the identity of the seed perseveres in the continuum of the samtanna.

In the Abbidharma Treatise Conforming to the Correct Logic, and the Treatise Clarifying Abbidharma Tenets, Sanghabhadra uses the example of the seed of rice to illustrate how the identity of a living entity is retained through material transformation (Skt. parināma; Ch. zbuanbian 轉變 $)^{24}$ in the pürvabhava. In his argument, Sanghabhadra conceptualizes the life cycle of the seed of rice as consisting of five stages of material transformation: the rice seed germinates into the plant that produces the seeds; the seed is ground into flour; the seed is consumed by an animal; the seed is digested by an animal; and the seed is scattered back into the terrain. ${ }^{25}$ The cycle restarts as

24 In Nyāyanusāra śāstra, Apidamo shun zhengli lun, $T$ no. 1562, 29: 72.733c21-22, Sanghhabhadra rejects the Sānkhya notion of transformation (parināma) as the transformation of one thing characterizable by an essential nature. He writes: 'all conditioned dharmas arise and cease in accordance with causes and conditions. They do not undergo transformation according to the causes and conditions of an essential nature’. 又諸有為法, 隨因緣生滅, 不隨因緣 本性轉變.

${ }^{25}$ Nyāyanusāra śāstra, Apidamo shun zhengli lun, T no. 1562, 29: 24.474b610, reads: 'We liken it [the continuum] to a one seed of rice that serves as the causal basis for five things: what grows into the sprout, the flour, the food, the dessicated grain, and the scattered grain. In this way, one continuum of the sentient being in one transmigratory realm (Skt. gati) serves a causal basis in five ways. This refers to the sprout that is capable of serving as causal basis in five ways. If it meets with congenial conditions, then it gives rise to its own kind of fruit. In 
the causal bases, embedded within the seed of rice, initiate a series of events, beginning with the germination of the seed and terminating with the maturation and dissemination of the seeds of the new plant. The seed that initiates the five stages of material transformation survives as it provides the causal bases necessary to renew the cycle of growth and development of a new plant.

In his commentarial works, Sanghabhadra is at pains to disabuse his Brāhmanical interlocutor (Skt. pürvapakșin; Ch. lundi 論敵) of the idea that the continuity of the plant through changes in the life cycle is due to a permanent quality (Skt. guna; Ch. de 德) that is inherent to the seed. The theorists of the Brāhmanical Sānikhya tradition hold that, although parts of the seed are altered during growth, the plant retains a continuous identity throughout all stages of development because the guna of the seed remains unchanged. ${ }^{26}$

this way, the continuum of a sentient being possesses five causal bases. Thus, we avoid the error of the person (Skt. pudgala), having ceased, only gives rise to its own kind of thing (i.e., another human).’ 如一稻種, 為芽麨飯灰散五因. 如是有 情一趣相續, 為五因故. 謂一稻種, 能為五因. 若遇順緣, 便生自果. 如是一趣有情 相續, 具為五因. 若遇如是順緣和合, 便生自果. 故無人等滅, 唯生自類過.

By speaking of things able to become a certain type of thing, only in meeting with conditions congenial to it becoming that sort of thing, Sanghabhadra attempts to avoid the error of things only being able to bear sui generis effects. For example, humans can be reincarnated as animals, and vice versa. Thus, having ceased, one thing does not necessarily arise as the same type of thing.

26 The modern scholar-monk, Yinshun, describes the Sānkhya theory of cause-and-effect in his lecture notes on the stanzas of the Mülamadhyamakakārikā of Nāgārjuna (Yinshun, Zhongguan lun song jiang ji, 360): 'The Sānikhya masters postulate that the effect pre-exists in the cause. For instance, they say that there is oil in the vegetable dish. The oil is the effect and the vegetable dish is the cause. If there is no effect already pre-existing in the cause, then why does oil come from the cooked vegetable? Supposing that where there is no oil, oil can emerge, then the stone does not contain oil, so why does oil not emerge from it? Hence, we can see that the effect pre-exists in the cause'. 一、數論師主張因中 有果, 如說菜子中有油, 油是果, 菜子是因. 如因中沒有果, 菜子中為什麼會出油? 假使無油可以出油, 石頭中沒有油, 為什麼不出油? 可見因中是有果的. 
Vasubandhu and Sanghabhadra endorse the Abhidharma tenet that the casual bases in the dharmas potentiate the developmental changes in the plant. They contend that the continuity of the plant can be explained by the causal efficacy and the causal capability of the seed rather than by a permanent or enduring quality within the seed. The temporal and spatial discontinuities that result from the material transformations of development are contained within the samtāna of the plant, and thereby produce the appearance of the ongoing being of the living entity.

Sanghabhadra recognizes the spatial and temporal aspects of the dharmas of the seed and the sprout, and notes that when the dharma of a seed perishes, the dharma of the sprout emerges in a different location and time. In his analysis of the example of the seed becoming the sprout, Sanghabhadra invokes the Abhidharma principle that two dharmas, such as a seed and a sprout, cannot occupy the same place at the same time. ${ }^{27}$ In the Treatise Conforming to the Correct Logic of Abbidharma Sanghabhadra writes:

It is a mistake to say that the seed and the sprout grow and terminate in the same locus. The continuum of the seed engenders the sprout. Although the seed and sprout are in an uninterrupted continuum, the seed and the sprout do not occupy the same location.

種芽同處生滅失, 以種相續生芽等時. 雖無間斷, 非無處異. ${ }^{28}$

Vasubandhu uses the idea that the seed and sprout occupy different spatial loci to articulate the relationship between a dead body and the intermediate being that survives death. He avers that the samtannas of

27 Abbidharmakośa, 12a-b, reads: 'Two things do not occupy the same place; since it arises from two causes, it does not arise as a samtāna'. Pradhan, ed., Abhidharmakośa, 120-21: sahaikatra dvayābhāvāt asantānād dvayodāyāt. Xuanzang, trans., Apidamo jushe lun, T no. 1558, 29: 44.b20: 一處無二並; 非相 續二生. In Tibetan, D no. 4089, 140: 7a.6-7a.7: gcig na lhan cig gnyis med phyir / rgyun min phyir gnyis las byung phyir I

28 Nyāyanusāra śāstra, Apidamo shun zhengli lun, T no. 1562, 29: 24.474.b11. 
a dead body, and the samtannas that form the intermediate being that arise from a dead body and continue after death, arise in two places and times, and are therefore temporally and spatially separate. ${ }^{29}$ Like the seed and the sprout, the body that decays after death, and the intermediate being that arises in the moment after death, are distinct from one another.

\section{Surviving Maranabhava, the Time of Becoming Deceased}

Throughout their doctrinal masterworks, Vasubandhu and Sanghabhadra maintain the Sarvāstivāda Abhidharma tenet that a sentient being survives corporeal death, or maranabhava, the time of becoming deceased, and continues into the afterlife. In their discourses on maranabhava, Vasubandhu and Sanghabhadra posit that the demise of the material skandha, or the rupaskandha, of a sentient being results in the death of the material body. Corporeal death, however, does not mark the end of the continuum of a sentient being.

In the Treasury of the Abhidharma, and in the commentarial works on this text, Vasubandhu and Sanghabhadra define the death of the body as the moment when the skandha of the material corporeal body (Skt. rüpaskandha; Ch. seyun 色蘊) becomes disaggregated from the four mental skandhas of sensation, perception, impulse, and consciousness. ${ }^{30}$ Sanghabhadra, in the Chinese translation of

29 The corresponding Tibetan text in Sütrānurūpā-vrẹtti, D no. 4091, 141: 135b.2, reads: 'Because it suddenly exists as an entity, where it dies is not where it is reborn'. Cig car du yod pa'i phyir 'chi ba dang skye ba'i srid pa ji lta ba bzhin du ni ma yin no /

30 Xuanzang's translation of Vasubandhu's Abbidharmakośa-bhāṣya, Apidamo jushe lun, T no. 1558, 29: 10.52.b05, reads: 'Having deserted this body, the four non-physical skandhas transmigrate towards the next rebirth'. 四無色蘊捨 此身已, 轉趣餘生. Nyāyanusāra śāstra, Apidamo shun zhengli lun, T no. 1562, 29: 24.474b02-3, reads: 'The four immaterial aggregates (i.e., the four mental skandhas) continue uninterruptedly and without any hiatus. When they are 
the Abbidharma Treatise Conforming to the Correct Logic, employs the doctrine of momentariness to articulate how a sentient being survives maranabhava in terms of the continuous arising and ceasing of the skandhas. He defines the 'moment of death' (Skt. maranaksanam; Ch. si cha'na 死刹那), as the specific time when the skandhas of the 'final dying consciousness' (Ch. sishi 死識) of the deceased being cease, and the skandhas of the 'new living consciousness' (Ch. shengshi 生識) of the intermediate being arise. ${ }^{31}$

\section{Surviving Maranabhava: The Transformation of the Fruit- Bearing Plant}

In the Treatise Clarifying Abbidharma Tenets, Sanghabhadra employs the example of the transformation of a seed into the sprout, the flower, and the fruit of a plant, to illustrate the Buddhist teaching of how a sentient being survives maranabhava by assuming different forms. ${ }^{32}$ Within this analogy Sanghabhadra depicts the transforma-

projected forth they provide the conditioning power (for the samtana). In the realm of sensory desire (Skt. kāmadhātu) and the rüpadhātu it (the samtāna qua conditioning power) causes the skandhas to arise simultaneously with a rüpa'. 四無色蘊. 無間無斷, 為緣引發. 欲色界中, 與色俱生. 諸蘊令起, 故彼色起.

31 Sañghabhadra, Nyāyanusāra śāstra, Apidamo shun zhengli lun, T no. 1562, 29: 24.474a23-25: 'Thus, in the state of becoming deceased (Skt. maranabhava), consciousness ceases in the very same place that consciousness arises anew in the intermediate being. Each moment of consciousness arises, one after another, in one place ahead of another, up until the point that the intermediate being ceases, and is reborn into the state of becoming reincarnated (Skt. upapattibhava). At that point, there is nothing that further becomes reborn as an intermediate being'. 如是死有於此處滅, 即於此處中有復生. 後後念生, 即前前處, 乃至中有 滅, 即此生有生, 是則應無往餘生義.

32 In the Nyāyanusāra śāstra, Apidamo shun zhengli lun, T no. 1562, 29: 24.474b13-15, Sanghabhadra states that the seed survives the 'time of cessation' by transforming into the seedling and sprout: 'When it [the seed] is destroyed and perishes, the conditions of the water, etc., which blend and assimilate 
tion of a plant during the four stages in the life of the fruit-bearing plant: the seed, the sprout, the flower, and ultimately, the fruit, as equivalent to the transformation of a sentient being during the Buddhist cycle of: pürvabhava, maranabhava, antarābhava, and upapattibhava. Sanghabhadra avers that a sentient being, like a plant, survives the stages of life, albeit in different forms, within the continuous arising and ceasing of the skandhas in samtāna. According to Sanghabhadra, insentient life forms, including plants, and sentient life forms, including non-human animals and humans, are composed of skandhas. Insentient life forms bear only one type of skandha-the rüpaskandha-while sentient beings bear all five types of skandhas. ${ }^{33}$ Although the Abhidharma Buddhist tradition does not consider a plant to be a fully-fledged sentient being with a mind and sensory faculties, ${ }^{34}$ the fundamental principle of growth and development

together [with the material of the seed], enable the capacity [for the seed] to serve as the generative cause for the much bigger sprout-aggregation. So, at the time that the seed has perished, it has already emerged as the sprout in a distinct location'. 於滅壞時, 由水等緣和合攝助, 能為鹿大芽聚生因. 於種滅時, 芽異處起.

33 Sañghabhadra says in his Nyāyanusāra śāstra, Apidamo shun zhengli lun, $T$ no. 1562, 29: 12.402c11, and Apidamo zang xianzong lun, T no. 1563, 29: 7.807c21, that: 'insentient beings only bear one [type of] skandha'. 無有情唯具一蘊.

34 As elucidated in Schmithausen's study, Problem of the Sentience of Plants in Earliest Buddhism, plants are not considered to be sentient because they do not evince sensory faculties or indriyas. The reviewer for Journal of the Royal Asiatic Society (JRAS), Karel Werner, summarizes Schmithausen's major findings: 'defining the problem from the angle of ethical precepts which require followers of Buddhism to abstain from killing or injuring living beings, he bases his understanding of what is a living or animate being on whether it is capable of "sentience", i.e., of perception and sensation. As the prevailing Buddhist position does not admit plants as sentient beings, they are not included in the above restrictive precept. However, since the Vedic, Jaina and post-Vedic Hindu sources admit sentience in plants and even seeds and elements, such as water and earth, the author wonders whether perhaps the earliest Buddhist position was not the same or similar, especially because explicit positions in the matter were formulated comparatively late'. See Werner, 'Book Review', 183. 
through material transformation in the continuum, holds true for sentient beings as well as for insentient living things.

For Sanghabhadra, the remarkable transformation of a seed into a fruit-bearing plant illustrates the discernable and discrete stages of a continuum of a living entity. Each stage in the life cycle of the plant is distinct and impermanent: beginning with the initial seed, to the germination of the sprout, to the blossoming of the flower, to the fructification, and then to the dispersal of the seeds as the process of germination of the sprout begins anew. The causal efficacies and capacities that are inherent in the initial seed sustain and potentiate each moment of transformation and change. The survival of the seed in the form of the sprout, the leafy plant, the flower, and the fruit illustrates the broader principle of the continuation of life of through dramatic material transformations.

In his example of the continuity of the seed in the development of a plant in the Clarification of Abbidharma Tenets, Sanghabhadra illustrates how the theories of momentariness and the continuum explain the survival of a living entity throughout all stages of a life cycle. During each stage of the development of the plant, the rupaskandhas that make up the continuum of the plant arise, abide, and cease from moment to moment. Each of the bundles of rupaskandhas that comprise the seed exist for a moment in a specific location, cease in the same location, and then arise in an immediately neighboring place. The continuity of rüpaskandhas in samtāna provides a rationale for why a time-lapsed video of the transformation of the seed into a fruit-bearing plant appears seamless to the viewer, without temporal or spatial gaps. The discontinuities between the stages of the seed taking sprout, the stem leafing out, the leafy-plant forming pedals, and the flower bearing fruit are not discernable because of the continuous flow of the samtana. The Abhidharma theorists employ this evocative metaphor to prove that a sentient being survives the material deprivation of the body of maranabhava and continues into the afterlife, albeit in other forms. 


\section{Surviving the Antarābhava, the Intermediate State}

Vasubandhu and Sanighabhadra uphold the Sarvāstivāda Abhidharma tenet that a sentient being survives the moment of dying, the maranabhava, and transitions into an intermediate state of being, the antaräbhava, prior to becoming reincarnated into a new corporeal form. In their exegeses on the nature of the continuum located in chapter three, 'On the Discrimination of Worldly Things' (Skt. Lokanirdes'a) in the Treasury of Abhidharma, and in their commentaries on this text, Vasubandhu and Sanghabhadra stipulate that after corporeal death, a samtāna of five skandhas exists in an intermediate state. ${ }^{35}$ Vasubandhu defines the intermediate state of the antaräbhava as the spatial-temporal location of the skandhas between bodily incarnations. ${ }^{36}$ In the Chinese translation of chapter three, verse ten of the Treasury of Abhidharma by Xuanzang and his coterie, Vasubandhu states:

死生二有中 There is an interval between the states of becoming deceased and of becoming reborn;

五蘊名中有 The five skandhas describe this intermediate state.

35 For instance, Sanghabhadra comments in Clarification of Tenets, in a discussion of Abbidharmakośa 3.10, Apidamo zang xianzong lun, T no. 1563, 29: 13.834a28: 'after maranabhava and before upapattibhava, an entity arises. It is complete in the five skandhas and reaches the place of rebirth'. 死後生前有自體 起, 具足五蘊為至生處.

${ }^{36}{ }^{*}$ Mahāvibhāșa, fascicle 68 , states that there is no antarābhava in the interim between dying out and becoming reborn in the arüpadhātu. Neither is there an antaräbhava between dying out in one of the two other realms and becoming reborn into the arūpadhātu. See *Mahāvibhāșā, Apidamo fazhi lun, T no. 1545, 27: 68.353.a0-8, which reads: 'Dying out from the rüpadhātu and becoming reborn in the arüpadhätu means living and becoming reborn again, since there is no intermediate state in the arūpadhātu. This extends to both ordinary humans (Skt. prthagjana) and sages (Skt. arrya)'. 色界㱛生無色界者, 謂生生有以無色界 無中有故. 此通異生及諸聖者. 
未至應至處 The future location of the skandhas of the deceased being is called the intermediate state.

故中有非生 This is the location where the skandhas of the deceased being have not become reincarnated. ${ }^{37}$

In the Abbidharma Treatise Conforming to the Correct Logic, Sanghabhadra explains that, following the demise of the rupaskandha that results in the death of the corporeal body, the remaining skandhas, carrying the mental constituents of the deceased being in a samtāna, arise in a location apart from the dead body. In a process described by the Abhidharma theorists as a 'spontaneous rebirth' (Skt. upa 万pad; Ch. buasheng 化生), ${ }^{38}$ the four psychological skandhas of the deceased being latch onto an intangible or 'extremely subtle' (Skt. accha; Ch. ji weixi 極微細 $)^{39}$ ruppaskandha. The four skandhas of the deceased being, and the ephemeral ruppaskandha, are collected together in a samtāna to form an upapāduka, an intermediate being. ${ }^{40}$

37 Xuanzang, trans., Abbidharmakośa, Apidamo shun zhengli lun, $T$ no. 1562, 29: 13.468a27. The corresponding Sanskrit text reads: gamya-deśa-anupetattvān-na-upapanno'ntarābhavaḥ|| 3.10. See Pradhan, Abhidharmakośa, 120.

38 Xuanzang's Chinese translations of Vasubandhu and Sanghabhadra's lengthy discourses on the topic of the upapāduka within the context of four modes of rebirth (Skt. catasro-yonayab; Ch. sisheng 四生) make use of a clever, but untranslatable pun on the two senses of the word-buasheng-as both, upa$p \bar{a} d u k a$ and 'to spontaneously become reborn'.

39 As both Vasubandhu's Abbidharmakosa-bhāsya, Apidamo jushe lun, T no. 1558, 29: 9.45c19, and *Mahāvibhāșā, Apidamo da piposha lun, T no. 1545, 27 : 70.362.a11, describe: 'the body of the intermediate being is of utmost subtlety'. 以 中有身極微細故. Ji weixi 極微細 is the Chinese term that Xuanzang also uses to render the Sanskrit word sükṣma - see his translation of Vasubandhu's bhāsya on chapter 2, verse 22 (T no. 1558, 29: 4.18b22) of Abbidharmakośa. For the Sanskrit text of this auto-commentary, see Pradhan, Abbidharmakośa, 52.

40 Under upapāduka, Sir. Monier-Williams Sanskrit Dictionary gives: 'a superhuman being, a god, demon'. Xuanzang's Chinese designation for this class of beings is buasheng 化生一transitional beings. This is the same word that Xuanzang uses for the fourth kind of mortal rebirth—via karmic transformation. 
Vasubandhu and Sanghabhadra describe an upapāduka, as the evanescent being that abides in the intermediate state between death and reincarnation. In the Abhidharma Treatise Conforming to the Correct Logic Sanghabhadra writes:

We grant that the intermediate being arises in a neighboring location from the dead body. The intermediate being does not overlap with the dead body, nor is it at a distance from the dead body. It continues in a series of arising and ceasing moments until it is associated with a new body (Skt. pratisamdhi). The samtāna of the reincarnated being perpetually arises in a continuous series in neighboring locations.

許隣死處中有生故, 謂許中有於前死處非隔·非即, 隣次而起. 如是 後後, 乃至結生, 恒隣次起. ${ }^{41}$

The spontaneous rebirth of an upapāduka differs markedly from the births of beings who gestate in an egg (Skt. andaja; Ch. luansheng 卵 生) or in a womb (Skt. jarāyuja; Ch. taisheng 胎生). The Abhidharma theorists posit that the body of upapāduka is composed of transparent bhautika (Ch. suozao se 所造色) matter, rather than the tangible, crude (Skt. audārika-rūpa; Ch. cuse 鹿色) matter of a body in the pürvabhava. ${ }^{42}$ Because an upapāduka comes into being without a rüpaskandha comprised of tangible matter, it does not bear the fleshy viscera associated with other forms of life.

While the attenuated form of an intermediate being is fragile, an upapāduka survives in the antaräbhava for a minimum of seven, and a maximum of forty-nine, days. ${ }^{43}$ An upapāduka in the intermediate

41 Nyāyanusāra śāstra, Apidamo shun zhengli lun, T no. 1562, 29: 23.468c23-25.

42 For a discussion of the intangible bhautika matter making up the body of the intermediate being, see Kritzer, 'An Átman by Any Other Name', 8.

43 Xuanzang's translation of the *Mahāvibhāsāa gives two diverging opinions on the duration of the antaräbhava. Vasumitra 世友 says that it lasts for a maximum of only seven days, while Śarmadatta 設摩達多 says that it lasts for a full period of forty-nine days or 'seven weeks' (Ch. qiqi 七七). The editors of the ${ }^{*}$ Mahāvibhāșa are agnostic on the question of the full duration of the antarābhava, 
state can take the form of: a winged apsarā (Ch. feitian nüshen 飛 天女神), a kalavinka (Ch. jialingpiqie 迦陵頻伽), a gandharva (Ch. qiantapo 乾䦮婆; 揵閣婆), ${ }^{44}$ a garuda (Ch. qielouluo 迦楼羅; jielucha 揭路茶), or a nāga (Ch. naqie 那伽). According to the estimates provided by Vasubandhu and Sanghabhadra, upapādukas are the most populous form of life in the great trichiliocosm (Skt. trisāhasramahāsāhasralokadhātu; Ch. sanqian daqian shijie 三千大千世界), the entirety of the known universe. ${ }^{45}$ This view holds that upapādu$k a s$ are even more numerous than insects.

although they endorse Vasumitra's view that there is no determinate duration for the intermediate state within the timeline of either one, or seven, weeks. They cite the view: 'Bhadanta (Vasumitra) is of the opinion that there is no determinate limit [to the duration of the intermediate state]. This means that if the conditions of life converge swiftly, then the body of the intermediate being abides for only a short time. If the conditions of life take a longer time to coalesce, then only when those conditions have converged, does the being become reincarnated (pratisamdhi). Thus, there is no determinate limit [to the duration of the antarābhava]'. 大德說日，此無定限. 謂彼生緣，速和合者. 此中有身，即少時住. 若彼生緣, 多時未合. 此中有身, 即多時住. 乃至緣合, 方得結生. 故中有身, 住無 定限. (Apidamo da piposha lun, T no. 1545, 27: 70.361b14-17).

44 Bhikku Anālayo writes: 'The Buddhist conception of a gandhabba appears to have its roots in the Vedic gandharva, which had the particular function of transmitting things from one world to another'. See his article, 'Rebirth and the Gandhabba', 96. Lamotte, La Traité de la grande vertu de sagesse, 614, writes: 'Les Gandharva sont des artistes divins qui jouissent D’un Bonheur égal à celui des dieux; ils possèdent la sagesse (prajñ $\bar{a})$ et savent distinguer le beau du laid'.

45 Xuanzang, trans., Abbidharmakosáabāssya, Apidamo jushe lun, T no. 1558, 29: 8.44a14: 'What is the most predominant form of birth? It should be said that the most predominant form of birth is the upapa $\bar{a} u k a$ '. 一切生中, 何生最勝? 應 言最勝, 唯是化生. For the corresponding Sanskrit text, see Pradhan, Abhidharmakośa-bhāsyya, 116. Nyāyanusāra śāstra, Apidamo shun zhengli lun, T no. 1562, 29: 22.467c03-4, and Apidamo zang xianzong lun, T no. 1563, 29: 13.834a08-9, read: 'The upapadukas are the most populous. That is to say, it is because of the fact that the minority of beings in both the two (i.e., humans and devas) and 


\section{The Body of the Upapāduka}

The * Mahāvibhāșā, the Great Abhidharma Commentary, a touchstone work of Sarvāstivāda Abhidharma, and a key source for the doctrinal masterworks composed by Vasubandhu and Sanghabhadra, defines the intermediate samtana as the continuum of skandhas that perseveres from the moment after maranabhava, to the moment of reincarnation (Skt. pratisamdhikșana 結生刹那). ${ }^{46}$ Vasubandhu and Sanghabhadra agree that the samtanna of the ephemeral upapāduka is comprised of five skandhas: the four psychological skandhas of the deceased being, and the subtle rippaskandha that is acquired in the moment after death.

In their translation of verse eleven in chapter three of the Treasury of Abhidharma ${ }^{47}$ by Vasubandhu, Xuanzang and his team of translators interpolate the phrase, 'body of the intermediate being' (Ch. zhongyou shen 中有身), to underline the point that an intermediate being, because it possesses a subtle rüpaskandha, maintains the semblance of a bodily form. The upapādukas who abide in the liminal state between corporeal incarnations are considered by Vasubandhu

three (i.e., non-human animals, pretas, and narakas) destinies of rebirth, as well as all of the intermediate beings, are born through spontaneous generation'. 化生 最多, 謂二趣全三趣少分及諸中有. 皆化生故.

${ }^{46}{ }^{*}$ Mahāvibhāșā, Apidamo da piposha lun, T no. 1545, 27: 192.310a18-9: 'The intermediate samtāna refers to the arising of the intermediate skandhas from the cessation of the skandhas of maranabhava. These intermediate skandhas continue upon the skandhas of the maranabhava, hence they are called the

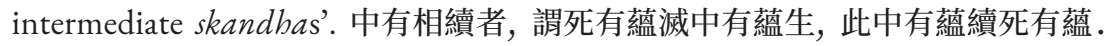
是故名為中有相續.

47 Xuanzang's translation of Abhidharmakośabhāsya AKBh $3.13 \mathrm{~cd}$, Apidamo jushe lun, T no. 1558, 29: 9.46a24, reads: 'the intermediate body being of a generic type is visible (in the intermediate state)'. 此中有身同類相見. The corresponding Sanskrit text (Pradhan, Abhidharmakośa-bhāṣya, 124) reads: samānajātīyair eva antarābhavair drisyate. Paramārtha's (T no. 1559, 29: 6.202c29) Chinese contains no mention of the 'intermediate body': 'intermediate beings in the same transmigratory path are visible to one another'. 若同生道中陰. 定互相 見. 
and Sanghabhadra to be 'barely alive' 48 in that they exist in extremely attenuated apparitional forms.

Although an upapāduka persists in an attenuated bodily state, without the viscera associated with a fleshy body, Vasubandhu and Sanghabhadra are adamant that the sensory and vital functions of the upapāduka are sustained by a collection of indriyas that are clustered within the samtana of the five skandhas. ${ }^{49}$ Vasubandhu and Sanghabhadra determine that an intermediate being bears the faculties (Skt. indriya; Ch. gen 根), the sensory, physical, psychological, and spiri-

48 In his 'Refutation of the Theory of the Ātman (Atmavāda)' (Ätmavādapratisedha), Vasubandhu classifies the view that upapādukas represent fully-fledged 'sentient beings', as heterodox and lacking scriptural corroboration ( $T$ no. 1558, 29: 30.155b6-14). He writes: 'The foregoing words from the cited scripture are meant to induce understanding that the pudgala can be described as impermanent and not real in nature. Rather, it is identified with the five appropriating skandhas that beset one with heavy burdens. The bearer [of this heavy burden] what draws forth the skandhas from preceding to subsequent moments. Thus, the pudgala does not really exist. The pudgala does not really exist since the sūtras reject it, just as they reject the heterodox view that upapādukas are fully-fledged sentient beings. Who says that the upapādukas are fully-fledged sentient beings? If the Buddha spoke about it, then I will proclaim it to be real. To negate the upapāduka, so defined, would be classified as a heterodox view, because the skandhas of the upapāduka are real'. 如上所引人經文句. 為令了此 補特伽羅可說無常非實有性. 即五取蘊自相逼害得重擔名. 前前刹那引後後故名 為荷者. 故非實有補特伽羅. 補特伽羅定應實有. 以契經說諸有撥無, 化生有情邪 見攝故. 誰言無有化生有情? 如佛所言, 我說有故. 謂蘊相續能往後世不由胎卵濕 名化生有情. 撥此為無故邪見攝. 化生諸蘊理實有故. For corresponding Sanskrit text, see Pradhan, Abhidharmakośa-bhāsya, 468. Reference has been made to the English translation of Pruden, Abhidharmakośa-bhāsyam of Vasubandhu, vol. 4, 1330 .

49 In the Abhidharma taxonomy of twenty-two faculties, the mental faculties of mind and aversion are grouped together under the four psychological skandhas, while the seven physical faculties (Skt. sapta-rüpêndriyāni; Ch. qi youse gen 七有色根), a rubric including the five ordinary senses (1-5), procreation (6), and vitality (7), are grouped together under the rüpaskandha. 
tual capacities, that sustain all sentient beings. ${ }^{50}$ To undergird their theoretical position regarding the bodily composition of upapadukas, Vasubandhu and Sanghabhadra enumerate the precise number of faculties that are possessed by an upapaduka to maintain the state of being 'barely alive' in the antaräbhava.

In their translation of the ancient Abhidharma Treatise on the Basis of Gnosis (Skt. Abhidharmajñannaprasthāna sāstra; Ch. Apidamo Fazhi lun 阿毘達磨發智論), a primary source for the later Abhidharma work of Vasubandhu and Sanghabhadra, Xuanzang and his collaborators postulate that 'the intermediate beings possess a minimum of thirteen, and a maximum of nineteen, faculties' ${ }^{51}$ The thirteen faculties enumerated in the Jĩānaprasthāna śāstra are the five ordinary senses of vision: (1), audition (2), olfaction (3), gustation (4), tactition (5), a coordinative mind to direct the senses (6), the two embodied faculties of male or female procreation (7), vitality (8), together with the five hedonic faculties of joy (9), suffering (10), pain (11), pleasure (12), and aversion (13). The nineteen faculties also include the five spiritual faculties of faith (15), vigor (16), recollection (17), concentration (18), and wisdom (19).

While supporting the theory that the 'barely alive' upapādukas possess indriyas, located within the Jñanaprasthāna sástra, Vasubandhu and Sanghabhadra agree with more attenuated assignment of faculties of the upapädukas found in the *Samyuktâbhidharmabrdaya (Ch. Za apitan xin lun 雜阿毘曼心論) rendered into Chinese

50 Vasubandhu states that all intermediate continua with supranormal powers (Skt. r $d d h i)$, such as the 'divine eye' (Skt. divyacakșur), are constituted in a 'bundle of five faculties' (Skt. samagrapañcêdriya) - namely, vision, tactition (kāyêndriya), mind, aversion, and vitality. For the Sanskrit text of this passage, see Pradhan, Abbidharmakośa-bhāsya, 3.14c, 125.

51 Jũānaprasthāna śāstra, Apidamo fazhi lun, T no. 1544, 26: 15.997a26-7: 'The intermediate being possesses nineteen [faculties], at the maximum, and thirteen [faculties], at the minimum'. 中有, 極多十九, 極少十三. Also see Sanghadeva's translation of Jñanaprasthāna, which corroborates the assignments of maximum and minimum faculties found in Xuanzang's translation, Apidamo baqiandulun, T no. 1543, 26: $15.874 a 8$. 
by Sanghavarman (Ch. Sengqiebaluo 僧伽跋摩) during the fifth century. ${ }^{52}$ In the ${ }^{*}$ Samyuktâbhidharmabrdaya, the upapādukas are depicted as possessing a minimum of three faculties: mind, vitality, and tactition (Skt. kāyêndriya), and a maximum of eight faculties: the female and male procreative faculties, five physical senses, and vitality. ${ }^{53}$ This enumeration of faculties is congruent with the concep-

52 Saṃghavarman, trans., Samyuktâbhidharmahrdaya, Za Apidamo xin lun, $T$ no. 1552, 28: 8.940c21-22 reads: 'The androgynic upapāduka contains six [faculties], namely the five physical faculties [vision, hearing, taste, touch, and smell] and vitality. The monadically gendered [upapäduka] contains seven; the bimodally gendered, eight. This description applies uniformly across the $k \bar{a} m a d h \bar{a} t u$ '. 化生無形六, 謂五色根及命根. 一形七, 二形八. 此一向說欲界. Vasubandhu and Sanghabhadra come to accept these specific figures as well, with only minor modifications. In summary, the upapāduka necessarily possesses at least one three vital faculties of mind, vitality, and tactition (kāyêndriya). Their continued existence ranges from a minimum of three to a maximum of eight. The maximum of eight includes all five ordinary senses. * Mahāvibhāșāa, Apidamo da piposha lun, $T$ no. 1545, 27: 147.751c22-24, gives slightly different figures: 'upapādukas have either six, seven, or eight, faculties. The androgynic upapādukas have six faculties: namely, vitality, hearing, smell, and taste. The bimodally-gendered have seven: namely, the six previous, including one of the gendered procreative faculties. The hermaphroditic upapādukas have eight: namely, the aforementioned six along with both male and female gendered procreative faculties'. 化生得六, 或七或八. 無形者六, 謂眼耳鼻舌身命根. 一形者七, 謂前六及男女根 隨一.二形者, 八謂前六及男女根.

53 Earlier works of Abhidharma prior to Xuanzang had stated at least two, but it is not clear that Xuanzang endorses this doctrine. In the Jñanaprasthanna śāstra, Apidamo fazbi lun, T no. 1544, 26: 15.994b11-2, forming the most ancient stratum of the Abhidharma literature transmitted by Xuanzang, the view is found that 'in the realm of sensory desire, how many faculties are born within the continuum at the outset of its life? Reply: those born vivipariously, ovipariously, or born by spawning in moisture, obtain the two (namely, tactition and vitality)'. 欲有相續，最初得幾業所生根? 答：卵生、胎生、濕生得二. A quatrain enumerating the numbers of faculties born by upapadukas in the *Samyuktâbhidharma-hrdaya śāstra (Ch. Za apitan xin lun 雜阿毘暑心論), T no. 1552, 
tualization by Vasubandhu and Sanghabhadra of the upapādukas as living, but apparitional, beings.

\section{The Karma of the Intermediate Being}

The physical and mental faculties that are required for the survival of the upapāduka, are contained within the samtana of the five skandhas: subtle material form, sensation, perception, mental formation, and consciousness. While fragile and evanescent, the samtanna of the upapāduka carries psychological traces of the deceased sentient being, including the states of consciousness and the karma accumulated

28: 8.940c15-16, attributed to the Sarvāstivādin council member Dharmatrāta. The forth hemistich of this quatrain reads that '[when the upapādukas are initially born]...they have six [faculties] in the rüpadhätu and one [faculty] in the arūpadhātu'. 色六無色一. The six faculties pertaining to upapādukas in the rüpadhātu are the 'five physical [sensory] faculties, vitality, and one faculty of procreation, if bimodally gendered; if hermaphroditic, eight'. 五色根及命根; 一形七二形八. This treatise also says in the previous line of verse that non-human animals and upapādukas in the kämadhātu can survive while bearing only the two faculties of kāyêndriya and jivitêndriya (T no. 1552, 28: 940.c15). The Abhidharma Heart Treatise (Skt. *Abhidharmahrdaya śāstra; Ch. Apitan xin lun 阿毗昙心論), T no. 1550, 28: 4.829c16, of Sanghadeva characterizes certain upapādukas in the arüpadhātu as 'solely bearing the one (i.e., the faculty of vitality)'. The Treatise Containing the Essential Juice of the Abbidharma (Skt. *Abhidharmâmrtarasa śāstra, *Abhidharmâmrta śāstra; Ch. Apitan ganluwei lun 阿毘昙甘露味論), $T$ no. 1553, 28: 1.972a1, a text in two fascicle rolls translated into Chinese during the Northern-Wei Dynasty, attributed to the Sarvāstivādin Master Ghoșaka 翟沙, one of the members of the Great Sarvastivadin Council of 318 C.E., posits that the most attenuated form of upapāduka can survive between bodies with 'solely the one'. *Abhidharmâmrtarasa sástra reads: 'in the immaterial realm (arūpadhātu) initially it [the upapāduka] obtains a single faculty of vitality'. 無色界最初得一命根. In short, the idea that some spectral upāpādukas are 'singularly endowed with vitality' is found in some earlier Abhidharma works transmitted into China, but Xuanzang abjures it. 
in the purvabhava by a sentient being, into the next life. Karma is defined as the latent effects of the good and the bad actions taken by a sentient being in prior incarnations. After a course of up to forty-nine days in the intermediate state, the samtanna imparts the mental constituents, including the karma of the previous sentient being, into a new body at the time of reincarnation.

Vasubandhu writes in his auto-commentary to chapter three, verse fifteen of the Treasury of Abbidharma:

the movement of the samtanna from one life to the next is motivated by karma, klesias, and force of habit, which cause the skandhas of the intermediate being to continue onto [the next life] entering a womb. ${ }^{54}$

Here, kleśas refers to the negative psychological aspects of the sentient being, such as mental disturbances, afflictions, attachments, negative emotions such as greed and anger, and unwholesome cravings that trap a sentient being in samsāra. Samsāra, the endless cycle of birth and death, results in suffering. Vasubandhu avers that karma, kleśas, and force of habit propel the samtanna of the sentient being

54 Xuanzang, trans., Abbidharmakośa-bhāsya 3.18, Apidamo jushe lun, T no. 1558, 29: 47.c07-11: 'This arises, and thus that arises (Samyuktâgama 262) And so it is said, etcetera, with respect to dependent arising (pratitya-samutpā$d a)$. But if that were the case, is there an atman that you do not reject? There are only the skandhas. That is to say that we do not reject the atman that exists in name only as a provisional designation for the skandhas. Granted that is the case, it should be granted that the skandhas move from one life to another. But the skandhas are momentary, and thus incapable of transmigrating amidst this cycle. It is because the intermediate being is made up of afflictions (klesa) and actions of the force of prior habit, that the intermediate being continues on to enter into the womb'. 此生故彼生, 廣說緣起. 若爾何等我非所遮. 唯有諸蘊. 謂唯於蘊假 立我名非所遮遣. 若爾應許諸蘊即能從此世間轉至餘世. 蘊刹那滅於輪轉無能. 數習煩惱業所為故. 令中有蘊相續入胎. Reference has been made to Pruden's English translation, Abbidharmakośa-bhāsyam of Vasubandhu, 399, and to the French translation of de la Vallée Poussin, L'Abhidharmakośa de Vasubandhu, 57. 
through the intermediate state, and into a new reincarnation, thereby sustaining the cycle of death and rebirth.

\section{Proofs of the Existence of an Intermediate State}

According to Vasubandhu and Sanghabhadra, there is a distinct temporal and spatial interval between the loss of the ruppaskandha of the dead body and the arising of the five skandhas that constitute an intermediate being. The presence of a spatial interstice and temporal interval between the place and time of the death of the body, and the 'rebirth' (Ch. sheng 生) of an intermediate being, provides the Abhidharma theorists with a rationale for the existence of a transitional space and time between life in the pürvabhava, survival of maranabhava, and the locus (Skt. deśa; Ch. chu 處) of the intermediate state, or antarābhava..$^{5}$

In their Chinese translations of the Treasury of Abbidharma, the Abhidharma Treatise Conforming to Correct Logic, and the Treatise Clarifying Abbidharma Tenets, Xuanzang and his team dedicate one and one-half folio rolls to a discussion regarding the existence of a distinct spatial and temporal state between the death of a living

55 Nyāyanusāra śāstra, Apidamo shun zhengli lun, T no. 1562, 29: 23. 468b20-25, contains the objection that if the ruppaskandha of the dead body arises in the same place as the living skandhas of the intermediate continuum, there should be no interstice between death and life, and hence, no intermediate state: 'If the previous set of aggregates ceases in a different place, then, the subsequent set of aggregates should arise in a different place, and there should be no intermediate state. But how can one grant that the subsequent set of aggregates arise in a different place, and yet that there is no gap between the state of being dead and the state of being alive? It should be granted that what is subsequently born in this very same place from which the previous set of aggregates terminated, lacks an intermediate state because whether or not it is reborn, it would always lack causal efficacy'. 若異處前蘊滅已. 異處後生, 則無中有. 如何不許死有無間, 即於異處生有緢生. 若於此處, 前蘊滅已, 此處後生, 亦無中有, 是則應許. 若生不 生, 皆無用故. 
corporeal entity and the reincarnation of an entity into corporeal form. In their extensive treatises affirming the existence of an intermediate state, Sanghabhadra and Vasubandhu adduce the example of the image of the moon on the surface of a mirror. ${ }^{56}$ In this metaphor the Abhidharma scholars aver that the 'interstice' (Ch. zhongjian 中 間) of space between the surface of the mirror, and the image of the moon that is reflected onto the surface of the mirror, is analogous to the interstice of space that exists between a dead being and a reincarnated being. This space is conceptualized as the temporal and spatial location during which the samtanna of four skandhas abide between bodily incarnations. It is within this interstitial space that the intermediate being, or the upapāduka, abides.

In making their case for the existence of an intermediate state, Vasubandhu and Sanghabhadra draw upon the Abhidharma principle that two samtānas cannot occupy the same space. As the image of the sun reflected on the water and the surface of the mirror are composed of different materials, they are, by definition, two separate samtannas. Therefore, the image of the sun that is reflected on the surface of the mirror and the surface of the mirror itself do not occupy the same spatial or temporal locus. The Chinese translation by Xuanzang and his cohort of the auto-commentary by Vasubandhu on chapter three, verse eleven of the Treasury of Abhidharma reads:

Again, shade and sunlight never occupy the same locus. Now, if one hangs a mirror in the shade [in a shed situated close to a pond lit by the sun], one would vividly see in the surface of the mirror the reflection [of the sun on the surface of the water]. There should not be two [samtanas of the surface of the mirror and the reflection] coinciding with one another when they arise.

56 Xuanzang's translation of Abhidharmakosa-bhāṣya 3.11, Apidamo jushe lun, T no. 1558, 29: 8.44c08-9, reads: 'The reflection of the moon and the surface of the mirror are two separate continua'. 鏡面月像, 謂之為二. For the corresponding Sanskrit text see Pradhan, Abbidharmakośa-bhāsya, 120. 
又影與光未嘗同處. 然曾見鏡懸置影中, 光像顯然, 現於鏡面. 不應 於此, 謂二並生. ${ }^{57}$

Like the image that occupies a different space from the surface of the mirror, the samtanna of a dead body occupies a different space from the samtana of a reincarnated being. The conclusion that a dead body and a reincarnated being cannot occupy the same space at the same time is taken by Vasubandhu and Sanghabhadra as support for an interstitial afterlife, or an intermediate state.

The rival Abhidharma traditions of Sthaviravāda (Ch. Shangzuo $b u$ 上座部) and Vibhajyavāda (Ch. fenbie lun zhe 分別論者 $)^{58}$ deny the existence of an intermediate state between death and rebirth. In the discourses on the antarabbava, found in the Treasury of Abbidharma and commentarial works on this text, Vasubandhu and Sanghabhadra construct lengthy defenses of the venerable Sarvāstivāda Abhidharma doctrine of the intermediate state. ${ }^{59}$ In his Clarification of Abbidharma Tenets, Sanghabhadra mounts a spirited defense against the Sthaviravādin and Vibhajyavādin denial of the existence of an intermediate state between the moment of death and time of reincarnation. He begins by describing the interpretation of metaphor of the caterpillar enlisted by his rivals in their rejection of the intermediate state between. Sanghabhadra writes:

57 Abbidharmakośa-bhāsya, Apidamo jushe lun, T no. 1562, 29: 8.470a27-8. This is basically the translation of Pruden, Abhidharmakosa-bhāsyam of Vasubandhu, 384, from the French of de la Vallée Poussin, L'Abhidharmakośa, 35, with modifications.

58 For the identity of the Vibhajyavādins, see Bareau, Les sectes bouddhiques du petit vébicule, 165-71.

59 The Sarvāstivādin editors of the ${ }^{*}$ Mahāvibhāṣā, the Great Abbidharma Commentary, rejoin the Vibhajyavāda view which denies any hiatus between maranabhava and upapattibhava by pointing to one unwarranted consequence of maintaining such a view. In short, if 'one must abandon maranabhava before entering upapattibhava', then when a hell borne being is due to become reborn into the Avīci Hell, s/he must first abandon the rüpaskandha of the dead body before s/he obtains the new ruppaskandha of the rebirth destiny in hell. Howev- 
We liken [the continuity of the samtanna] to the continuous movement of the caterpillar. To move forward the caterpillar first moves its front legs and then moves its back legs. In this very way, the state of becoming deceased (Skt. maranabhava) is separate from the state of becoming reincarnated (Skt. upapattibhava). The caterpillar initially uses the front legs, and then retracts them as it reaches other locations. So why should an intermediate state exist?

猶如尺蠖, 前安前足, 後足後移. 如是死生, 方所雖隔. 先取後捨, 得 至餘方, 中有何用? ${ }^{60}$

The Vibhajyavādins argue that when viewed from above, the movement of caterpillar appears continuous, even though the forward movement of the caterpillar is initiated by the front legs and followed by the back legs. ${ }^{61}$ If one were not to notice the legs rapidly

er, if there were no hiatus between the state of becoming deceased and the state of becoming reincarnated, then a sentient being becoming reborn into the Avīci Hell would simultaneously belong to two transmigratory realms (gati) at oncethe realm of the human and the realm of the hellish beings. This is granted to be an impossibility, for such a sentient being, not yet having abandoned the dead body, would possess a mind simultaneously belonging to two transmigratory realms at once. The editors of ${ }^{*} M a b \bar{a} v i b h \bar{a} s \bar{a}$ regard this unwarranted consequence of a hell borne being belonging to two transmigratory realms at once, as grounds to reject the view that there is no interval between maranabhava and upapattibhava. In their words: 'it is impossible that two sentient minds [belonging to different realms] could simultaneously arise within one body'. 一身內二心 俱生 (Apidamo da piposha lun, T no. 1545, 27: 69. 358a16).

${ }^{60}$ Apidamo zang xianzong lun, $T$ no. 1563, 29: 13.837a04; argument also found in Nyāyanusāra sāstra, Za Apidamo xin lun, T no. 1552, 29: 24.474c08-10.

${ }^{61}{ }^{*}$ Sam ynuktâbhidharmahrdaya śāstra, Za Apidamo xin lun, T no. 1552, 28 : 11.963a18-20: 'If one initially takes up the living skandhas, and then abandons the dead skandhas, then the example of the twists and turns of the caterpillar is not logically appropriate. Why? Because there is the error that the transmigratory realms (gati) [of living and being dead] are not separate and the two consciousnesses [of the time of living and the time of being dead] would be combined. For 
moving and exchanging the burden of the weight of the creature, the slithering of the caterpillar across the ground would appear as a seamless vector of forward movement. The Vibhajyavādin argue that the unbroken movements of the caterpillar are analogous to the continuous movement of a sentient being transitioning from death to rebirth. ${ }^{62}$ The Sthaviravādin and Vibhajyavādin theorists state that, just as the back legs of the caterpillar follow the front legs, rebirth, or upapattibhava, follows immediately after corporeal death or maranabhava. ${ }^{63}$ The existence of an intermediate stage, or antaräbhava, is not evident in the movement of the caterpillar. In his analysis of the metaphor employed by the Sthaviravādin and Vibhajyavādin, Kritzer writes: 'just as a caterpillar moves along by placing its front foot down and then immediately moving its rear foot, so does a person give up the maranabhava immediately upon obtaining upapattibhava' ${ }^{64}$

In his defense of the existence of the antaräbhava, Sanghabhadra poses a rhetorical question to his Vibhajyavādin interlocutor: If the front and back legs of the caterpillar succeed one another in enabling the caterpillar to move forward, how can the gap between the front

this reason, we should say that there exists an intermediate state [between death and rebirth]'. 若先取生陰, 而捨死陰. 如折樓虫者不然. 何以故? 趣不別及二識合 過故. 是故說有中陰.

${ }^{62}$ Xuanzang's translation of the ${ }^{*} M a h \bar{a} v i b h \bar{a} s \underline{a}$ reports the Vibhajyavāda interpretation of the simile of the caterpillar as follows: 'Whenever a sentient being moves from maranabhava to upapattibhava, it must abandon maranabhava before entering upapattibhava. We liken it to a caterpillar climbing up a blade of grass or a tree, etc. First the caterpillar places its front legs forward, and only then does it move forward on the back legs. By this reasoning, there is no error of the interruption between maranabhava and upapattibhava'. 諸從死有至生有時, 要 得生有, 方捨死有. 如折路迦緣草木等, 先安前足, 方移後足. 是故死生中無斷過. (Apidamo da piposha lun, T no. 1545, 27: 69.358a10-13)

63 For the Sthaviravāda arguments against the intermediate state, see Cuevas, 'Predecessors and prototypes', 282-3. For the Vibhajyavādins against the intermediate state, see Kritzer, 'Rūpa and the Antaräbhava', 237-9.

${ }^{64}$ Kritzer, 'Rüpa and the Antaräbhava', 237. 
and back legs serve as an example supporting the non-existence of the intermediate state? In his interpretation of the simile comparing the movement of caterpillar to the relationship between maranabhava and upapattibhava, Sanghabhadra understands the gradual movement of the caterpillar along the ground as involving the smooth movement through the spatial interstice and temporal interval between where and when the maranabhava ends, and upapattibhava begins. ${ }^{65}$ For Sanghabhadra, the non-interruption in the movement of the caterpillar, even within the time that the front legs have ceased moving, and back leg have not yet set into movement, is an example of this smooth transition from one life to another through the intermediate state. Based upon this reasoning, Sanghabhadra concludes that the Vibhajyavādin interpretation of the metaphor of the caterpillar is flawed. Like the caterpillar moving forward along the ground, first, by engaging its front legs, and then, by engaging its back legs, the distinct stages in the life cycle of the sentient being succeed one another without hiatus or interruption.

${ }^{65}$ Sanighabhadra rejects the Vibhajyavādin theorists' conclusion that the uninterrupted movement of the caterpillar presupposes that there cannot exist any gap or hiatus between where and when the front legs cease action, and the back legs take up action. His criticisms of the Vibhajyavādin interpretation of the metaphor of the caterpillar in the Nyāyanusāra śāstra, Apidamo shun zhengli lun, $T$ no. 1562, 29:24, 474.c13-4, rest on the idea that the metaphor of the caterpillar is consistent with the notion of a locus (deśa) or interstice between where the front legs retract, and the back legs set into motion. Sanghabhadra concludes: 'Moreover, the logical reasoning [of the Vibhajyavādins] with the metaphor of the caterpillar is unestablished. Due to its insect-body the caterpillar continues without interruption-initially placing the front legs forward and later moving forward on the rear legs, it is logically possible that the spatial locations [of the front and rear legs] are separated by a space (i.e., the intermediate state). Having a body in becoming deceased (in maranabhava) and becoming reborn (in upapattibhava) are separated by a spatio-temporal interstice'. 又尺蟭喻, 其理不成. 以 彼蟲身，中無間絕. 安前移後，處隔可然. 死生有身，中間隔絕. 


\section{Surviving Reincarnation: The Pratisamdhikāla}

In their argumentation for the survival of the sentient being Vasubandhu and Sanghabhadra describe reincarnation (Skt. prati-

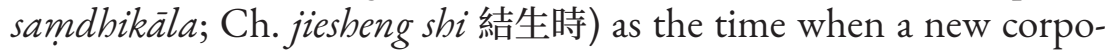
real ruppaskandha is bundled with the four skandhas carried within the samtana of the upapáduka. The event of the merging of the four skandhas of the intermediate being with the rüpaskandha of an embryo, marks the beginning of the initial kalala stage (Ch. jieluolan 羯羅藍) of embryogenesis. ${ }^{66}$ When the ruppaskandha of an embryo becomes associated with the skandhas of the intermediate being from a past life, the process of reincarnation begins. ${ }^{67}$

66 Sañghabhadra, Nyāyanusāra śāstra, Apidamo zang xianzong lun, $T$ no. 1563, 29: 24.480a27, and Apidamo shun zhengli lun, T no. 1562, 29: 15.839c06-9, contain the description of how the intermediate being terminates in the insemination of the new embryo: 'while the physical basis and consciousness cease at death, they are capable of providing the generative condition for the intermediate being's consciousness, etc. The intermediate continuum is composed of skandhas whose karma consists in the delusion left over from a prior life. The samtāna moving towards the place it arises is like an illusion. When it reaches the mother's womb, the intermediate samtanna terminates. It is further capable of providing the causal conditions for the arising [of the skandhas] in the state of becoming reincarnated (Skt. upapattibhava)'. 死識與依, 俱至滅位. 能為中有, 識等生緣. 中 有諸蘊, 由先惑業. 如幻相續, 往所生處. 至母腹內, 中有滅時. 復能為緣, 生生有 藴.

67 Nyāyanusāra sāstra, Apidamo shun zhengli lun, T no. 1562, 29: 48.478a1-3): 'The impurities of the father and mother beget the kalala. It [the kalala] is born from impurities. There is no error here as far as contradicting the sütras. Other masters say: the mabābhütas of the [uterine] blood and semen in the state of transformation, form the faculties and their physical bases. The previous faculties of the intermediate being cease and the later faculties [of the reincarnated being] arise without interruption. The principle is the same as the seed ceasing when the sprout arises'. 父母不淨, 生羯刺藍, 依不淨生, 無違經失. 有餘師說: 精血大種, 於轉變位, 即作根依. 謂前無根, 中有俱滅. 後有根者, 無間續生. 如種與芽, 滅生 道理. 
Sanghabhadra writes that the cessation of the subtle rüpaskandha of an intermediate being leads to the arising of the four aggregates of sensation, perception, impulses, and consciousness into a newly sentient embryo. The ceasing of the consciousness and the psycho-physical basis (Skt. äśraya; Ch. suoyi 所依) of the skandhas of the intermediate being provides the generative conditions (Ch. shengyuan 生緣) for the arising of a new set of skandhas in the embryo. ${ }^{68}$

Sanghabhadra writes that the consciousness of the first moment of the new life form is informed by both the consciousness of the intermediate being and the innate (Skt. sababbü; Ch. jusheng 俱生) consciousness of the new embryo. ${ }^{69}$ In the kalala stage, the embryo is

68 Apidamo zang xianzong lun, $T$ no. 1563, 29: 13.839.c04-8, and Nyāyanusāra śästra, Apidamo shun zhengli lun, T no. 1562, 29: 24.480a26-b1, describe how the cessation of consciousness and the psycho-physical basis (ásraya) of the continuum at death provide the generative conditions for the arising of the continuum of the intermediate being: 'This continuum (samtana) of psycho-physical aggregates experiences factors such as lifespan, drawn forth by karma of delusion from previous lifecycles. With the power of the maturation (vipāka) of that karma, up until the time that it is exhausted, the consciousness at the time of becoming deceased, and its psycho-physical basis, in the stage of their concurrent cessation, are capable of providing the generative conditions for consciousness, etc., in the intermediate being (antaräbhavin). The various aggregates of the intermediate state persist on, like an illusion, due to previous karma, and head towards the locus of rebirth, until they reach the mother's womb. When the intermediate state has ceased, it [the continuum] is capable of engendering the aggregates of the state of becoming reincarnated (upapattibhava)'. 此 蘊相續, 領納先世, 惑業所引, 壽量等法. 彼異熟勢, 至窮盡時, 死識與依, 俱至滅 位, 能為中有, 識等生緣. 中有諸蘊, 由先惑業. 如幻相續, 往所生處, 至母腹內, 中有滅時, 復能為緣, 生生有蘊.

69 Apidamo zang xianzong lun, $T$ no. 1563, 29: 13.838b15-17: 'when the skandhas of the intermediate being cease, the skandhas of the reincarnated being arise. The rüpaskandha of the reincarnated being are engendered by the proper cause in the intermediate being. The blood and semen of the mother and father only serve as the generative condition. We liken it to the fertilizer, etc., that serves 
a droplet, yet possesses five skandhas. The living rüpaskandha of the kalala embryo nurtures the 'seeds' (Skt. bijas, ainkula; Ch. zhongzi 種子) of the seven physical faculties. ${ }^{70}$ Although it does not possess fully-fledged sensory indriyas, the kalala embryo is endowed with the capabilities required for a sentient being to survive and thrive.

\section{The Exposition of the Example of the Flame of a Candle}

Vasubandhu invokes the metaphor of the wick of a burning candle to describe how the samtāna of an intermediate being survives reincarnation. In this metaphor, the flame of an existing candle is used to light the wick of another candle. The transfer of the flame from one candle to another is analogous to the transfer of the samtanna of the five skandhas the intermediate being, to a new embryo. ${ }^{71}$ In his

as the supporting basis for the growth of the sprout from the seed'. 中有蘊滅, 生 有藴生. 生有色生, 正因中有. 父母精血, 但作生緣. 如種生芽, 依地粪等.

70 The explanation that the seeds of the seven physical faculties is found in *Mahāvibhāșā, Apidamo fazhi lun, T no. 1545, 27: 147.751b26-c6: 'Question, for what reason do the loci of those [i.e., physical faculties of procreation] only come to be during the stage of infancy?'問: 如何於少時, 頃便得爾所根耶?

'Reply: at that time (in the prenatal stage), although there are none of the salient features of the physical faculties, although the seed is already there. We liken it to mixing distilled saline-water, ghee, sweet honey, and rum, etc., together and then storing them in a single vessel. If you pick up a single drop with a blade of grass, all of the variegated flavours are present within that [single drop]. We should understand the kalala stage in this way, since the seeds of the physical faculties are already all present'. 答: 爾時雖無諸色根相, 而已具得彼根種子. 如清鹽 水酥. 蜜 - 沙糖酒等, 和合貯在一器. 若以草端, 露取一渧, 於中具有鹽等諸味. 羯邏藍位應知亦爾, 一切色根種子皆具.

71 *Abhidharmakośa-vrtti sūtrānurūpā, D no. 4091, 141: 137b.7-a.1, reads: 'momentary skandhas, referring to the feeble afflictions saturating the intermediate being that consists only in skandhas, as a continuum, transmigrate into the womb. We liken this to the momentary flickers of the lamp which are constantly transforming. In this there is absolutely no fault, because there is no attman. What 
description of the process of reincarnation, the skandhas transfer the information from the previous life, carried by the intermediate being, into a new embryo. This includes the genetic information imparted to the embryo by the biological father and mother, as well as the karma imparted to it by the intermediate being with which it merges during the moment of reincarnation. Vasubandhu and Sanghabhadra maintain that the transfer of the mental constituents and karma from one life to the next occurs within the moment to moment action of the samtāna, and without the presence of an àtman.

In the Treasury of Abbidharma chapter three, verse eighteen, Vasubandhu illustrates that the process of the transference of the samtana of the intermediate being into an incarnated form occurs without an àtman. In his Chinese translation, Xuanzang renders the sloka verse written by Vasubandhu as follows:

The samtanna is made up of the previous karma and afflictions (Skt. kleśas) and is only skandhas. It is not an atman. The intermediate being, existing in the form of the samtana, enters the womb. The samtana is like the [arising and ceasing] of the flames of a candle.

無我唯諸蘊, 煩惱業所為. 由中有相續, 入胎如燈焰. ${ }^{72}$

goes into the womb is a samtāna of the assemblage of plural skandhas consisting in psycho-physical formations (samskāra) of karma and affliction (kleśa)'. phung po skad cig ma de dag la ni / 'pho ba'i mthu med kyi nyon mongs pa dang las kyis yongs su bsgos pa'i phung po tsam srid pa bar ma zhes bya ba ni rgyun gyis ma'i mngal du 'gro stel dper na mar me skad cig ma'i rgyun gyis yul gzhan du 'gro zhes bya ba bzhin pas / 'di la nyes pa med do /de bas na bdag ni med kyi / nyon mongs pa dang las kyi mngon par 'dus byas pa'i phung bo rnams kyi rgyun ma'i mngal du 'gro zhes bya ba 'di grub po /

72 Xuanzang, trans., Abbidharmakośa 3.18, Apidamo jushe lun, T no. 1558, 29: 9.47b27-28. For the corresponding Sanskrit verse, see Pradhan, Abbidharmakośa, 129. Corresponding Tibetan translation by Jinamitra, et al., found at D no. 4090, 140: 123a.1. 
Sanghabhadra elaborates on the analogy of the flame of the candle in his explanation of the samtāna that survives biological death:

We liken the samtanna to the flame of a candle. Although the samtāna functions as the momentary [arising and] ceasing stream of preceding and subsequent causes and effects, without interruption, the samtanna is capable of reaching the next life. Therefore, although there is no atman, and the skandhas cease from moment to moment, it is established that the skandhas move towards the transmigratory realm of the next life. ${ }^{73}$

譬如燈焰, 雖刹那滅, 而能前後因果無間展轉相續, 得至餘方. 故雖 無我刹那滅, 而能往趣後世義成, 即此諸藴. ${ }^{74}$

Within the Brāhmaṇical Sānkhya and Vaiśeșika traditions of doctrinal thought, the teachings on the survival of death require the existence of an enduring and substantial àtman that works invisibly within the body to animate a sentient being and survives death and reincarnation. To Vasubandhu and Sanghabhadra however, the Buddhist conceptions of momentariness and the samtana provide a robust and plausible explanation for continuing physical and cognitive actions of a sentient being throughout the Buddhist life cycle. Vasubandhu and Sanghabhadra endorse the conceptualization of the survivability of the sentient being in the skandhas without the presence of a Brāhmanical àtman or self.

73 Nyāyanusāra śāstra, Apidamo shun zhengli lun, $T$ no. 1562, 29: 24.480b01-2: 'We liken it to the flame of a candle that ceases from moment to moment, yet is capable of moving to and from. Since the causes and effects are uninterrupted in their cooperation, the samtanna moves to other places. Hence, even without a self, it is established that the skandhas move from one life to the next, while ceasing from moment to moment'. 譬如燈焰, 雖刹那滅, 而能前後. 因果無間, 展轉相續, 得至餘方. 故雖無我, 蘊刹那滅. 而能往趣, 後世義成. Passage also found in Clarification of Tenets, T no. 1563, 29: 13.839c9-11.

74 Passage appears also in Apidamo xianzong lun, $T$ no. 1563, 29: 13.839. c9-11. 


\section{Sangghabhadra Contends That the Brāhmanical Atman Is Not the Locus of Transmigration}

Vasubandhu and Sanghabhadra take the example of the flickering of a candlewick to dispute the claims of the rival Brāhmanical theorists that the locus of transmigration is a singular and enduring entity. The flickering glow of a candle appears as a continuous and unitary flame. The flame, however, consists of multiple small units of flame that follow one another in a quick succession of moments. The metaphor of the flame draws a stark contrast between the Buddhist view of no-self (Skt. anātman) and the Brāhmanical view that a substantial self (Skt. àtman; Ch. shiwo 實我) or psychic person (Skt. purusa; Ch. shifu 士夫, shenwo 神我 $)^{75}$ constitutes the locus of transmigration.

Based upon the hallowed verses of the classical Sānikhya tradition, the Sänkbyakārikās of Kāpila, the purușa, or psychic person, comprises the essence of the atman. In the sixty-eighth stanza of the seminal Sänkhyakārikās, the biological death of a sentient being is depicted as when the purusa is liberated from its bodily fetters. ${ }^{76}$

75 Radich, 'Ideas about Consciousness', 480, shows that in fifth- and sixth-century Chinese Buddhist debates, 'the shenwo had emerged as a technical term for the àtman'. However, in the seventh-century, Xuanzang avails himself of the term shenwo to refer to the purusa, simpliciter, the first of the twenty-five elements (Skt. tattva; Ch. di 諦) posited in Sānkhya teaching. See Xuanzang's translation of Dharmapāla's *Catubśataka-vrtti (Ch. Dasheng guang bailun shilun 大乘廣百論釋論), $T$ no. 1571, 30: 2.197b23, for one such example. The purusa, simpliciter, is utterly inactive and consists in pure sentience. It is not an agent of physical action. Only when the shenwo becomes embodied in its material covering of prakrti (Ch. zixing 自性), the second element, and the faculties of physical action (Skt. karmêndriya; Ch. zuoye gen 作業根), does the psycho-physical organism become an agent of physical action. As such, physical actions such as breathing, walking, and talking happen not to the purusa, but to the embodied psycho-physical organism. See Bryant, 'Agency in Sāṃkhya and Yoga', 21, for an investigation of the nature of agency in Sānkhya teaching.

76 Reference has been made to the Sanskrit edition of Dutt, Sāikhyakārikā, 79, who translates the entire stanza as follows: 'After having deserted the body 
In this process, the purusa is extricated from the body and released into space within the cocoon of an 'ethereal body' (Skt. gubyasarira; Ch. xishen 細神). Concealed in life, the gubyasarira emerges during process of dying and provides the purusa with a container by which it transmigrates into the ether (Skt. $\bar{a} k \bar{a} s a$ ) for reincarnation into another corporeal body.

Sanghabhadra rejects the idea that a purusa or an atman is required to explain the process of transmigration and reincarnation. To disabuse his Brāhmanical antagonist of the postulate that a purusa, or spiritual core of the àtman, survives death, Sanghabhadra targets the doctrine of the substantial àtman. He writes:

Why do you posit that there exists an internally-functioning person (Skt. purusa)? The World-Honored One (Skt. Bhagavat) has already excluded the substantial atman posited by you - this is both the agent and patient of actions and is reborn into the next life (Skt. paralokam). It is for this reason that when Bhāgavan said: 'There exists karma and there exist the effects of matured karma (Skt. vipäka), ${ }^{77}$ he referred

and after the cessation of the Nature, the Spirit (i.e., purusa) acquires the salvation which is both certain and final'.

77 In the Ninth Chapter of his Abhidharmakosa-bhāsya, Vasubandhu identifies this passage as coming from the Paramārtha-sunyatā-paryāya 勝義空契經 ( $T$ no. 1558, 29: 30.155b26, corresponding to Pradhan, Abbidharmakośa-bhāsya, 468). The full passage cited in Abhidharmakośa-bhāsya 3.18a reads: 'There exists karma and there exists the effects of matured karma, but there is no agent who abandons these skandhas here and take up those skandhas there, independently of the causal relationship of the dharmas. Namely, if this exists, then that exists; through the arising of this, there is the arising of that, and so forth, etc. - [ that is,] dependent arising'. This is Pruden's (Abbidharmakośa-bhāsyam of Vasubandhu, 399) translation, with modifications, based on the French translation of de la Vallée Poussin (L'Abbidharmakośa de Vasubandbu, 57). The Sanskrit passage reads: Asti karmāsti vipākah kārakas tu, na upalabhyate ya imāms' ca skandhān; niksipaty anyāms' ca skandhān; pratisamdadhāty anyatra dharmasamketāt. tatra ayam dharmasamketo yad tasmin sati idam bhavati iti vistareṇa pratītyasamutpādaḥ. See Pradhan, ed., Abhidharmakośa-bhāșa, 129; 
to the capability of deserting this corporeal aggregate (Skt. ruppaskandha) along with the capability of continuing the other [four] aggregates, and so forth in detail (Skt. iti vistarena).

Again, how do we know this? You posit the substantial àtman as the agent (Skt. kartr), etc. However, in fact, it is unobservable (Skt. anupalabdhi), since it does not exist as a [tangible] entity.

Insofar as the ätman exists as a substantial entity, it possesses an unexperienced instrumental cause (Skt. karana), because its causal basis is unobserved.

如何執有內用士夫? 世尊亦遮所執實我. 是作受者, 能往後世. 故世 尊言: ‘有業有異熟, 作者不可得. 謂能捨此蘊, 及能續餘藴, 乃至廣 說.

復如何知? 所執實我, 是作者等, 實不可得, 為體無故. 為體實有, 有不得因, 無得因故. ${ }^{78}$

In this passage, Sanghabhadra takes issue with the doctrines of the psychic person and the substantial atman defended by the Brāhmanical theorists of the classical Sānkhya tradition. By the 'substantial àtman', Sanghabhadra specifically refers to the Sānkhya doctrine of the spiritual core of the sentient being that is believed to depart the body at death, transmigrate through the ether, and eventually become reincarnated in a new corporeal body. However, Sanghabhadra remains suspicious of the purusa, as it is described negatively as 'inactive' (Skt. nișkriya) and 'detached' (Skt. kaivalya) from material reality. According to the Sänkbyakārikā, the purusa alone exists in an inert, static state of pure sentience (Skt. caitanya). Hence, the purusa requires the dynamic powers of the embodied atman in order to accomplish actions. ${ }^{79}$ According to the

Shastri, ed., Sphuțārthā Abhidharmakośa-Vyākhyā of Yasomitra, vol. 2, 432. The corresponding passage in the Tibetan translation is found at $D$ no. 4090, 140: 122b.6.

78 Nyāyanusāra śāstra, Apidamo sbun zhengli lun, T no. 1562, 29: 24.479c4-9.

79 Watson, The Self's Awareness of Itself, 95, describes how, by conflating the puruṣa with the 'true soul', Sānkhya assigns active agency to the faculties: 
doctrinal schema laid out in the Sänkhyakārikā, although purusa cannot execute actions without the embodied atman, a purusa constantly directs the physical and cognitive actions of the atman in an executive capacity. ${ }^{80}$ While the purusa, simpliciter, is described as immutable and eternal, the purusa is said to play a provisory role in coordinating the ephemeral physical operations of the body, along with the cognitive operations of the mind such as walking and talking, thinking, and remembering.

The argument against the existence of the purusa presented by Sanghabhadra hinges on the premise that if the purusa were the executive operator coordinating the actions of the body and mind, then the purusa would be directly observable in sense perception. The purusa, which is postulated by the Sānkhya theorists as the initiating cause of bodily and mental action, is described as imperceptible to the naked eye. Sanghabhadra therefore concludes:

Our tradition maintains that the attman cannot exist as a real entity, because it is unobserved. It is not for any other reason (that the âtman does not exist).

The arisings of attachment to the atman do not go beyond the following four possibilities.

'Sānkhya souls are completely inactive experiences (bhoktṛ) in the form of pure sentience (Skt. caitanya): mental occurrences such as pleasure, pain and cognition thus happen not to them but to the psycho-physical organism, in particular, its mental faculties'.

80 Bryant, Agency in Sāṃkhya and Yoga', 21, pinpoints an issue surrounding the source of agency in Sānkhya philosophy: '...Agency in the Sānkhya perspective, has to be consigned to an entity other than purusa, which must be "unmixed" with such changeable qualities such as agency, and Sānikhya assigns this function either to buddhi, its covering of discrimination, or to the second evolute emanating from prakrti, abaikkāra, ego (literally: "I-maker"), defined as the function of conceit or ego (abbimāna)'. As Stcherbatsky, Soul Theory of the Buddhists, 3, writes: 'the position of an eternal passive Soul alongside with an active but unconscious intellect (buddhi) is indeed a very weak point in the Sānkhya system, a point which invites criticism'. 
我宗定許, 由我體無, 故不可得, 非餘因故. 諸起我執, 無過四種. ${ }^{81}$

At this point in his Treatise Conforming to the Correct Logic of Abhidharma, Sanghabhadra presents a catuskoți (Ch. siju 四句), or tetralemma:

Either the àtman you posit is, by nature, identical to [one of] the skandhas;

Or, secondly, the atman you posit is distinct from the particular skandhas, while residing in the collection of skandhas;

Or, thirdly, the attman you posit resides in the different skandhas and factors belonging the different skandhas;

Or, fourthly, the atman you posit is different from the skandhas as it exists entirely independently of them.

一執有我, 即䋹為性.

二執異蘊, 住在蘊中.

三執異蘊, 住異蘊法.

四執異蘊, 都無所住. ${ }^{82}$

In the above quatrain, Sanghabhadra lays out the four possible ways that the atman can be related to the five skandhas. They are: firstly, that the atman is identical to one of the individual skandhas; ${ }^{83}$ secondly, that the atman is separate from the individual skandhas, while residing in the collection made up of more than one skandha; thirdly, that the atman is distinct from the individual skandhas, while it is equivalent to the specific factors categorized under the taxonomy of five skandhas; and fourthly, that the atman is entirely

\footnotetext{
81 Nyāyanusāra śāstra, Apidamo shun zhengli lun, T no. 1562, 29: 24.479c9-10.

82 Nyāyanusāra śāstra, Apidamo shun zhengli lun, T no. 1562, 29: 24.479c11-12.

83 Kramer, Pañcaskandhakavibhāșa, xix: 'Sānkhya only regard rüpaskandha as ätmìa ("mine"), and all the other four skandhas as ätman. He [Sthiramati] thus claims that for the Sānkhyas the self is not only identical to vijñāna but also consists of the factors accompanying the mind'.
} 
unrelated to any of the five skandhas or to their collection. The four possibilities are meant to express the full range of ways that the atman could relate to the individual skandhas and to their collection in samtāna.

The argument summarized in the tetralemma sets up a basic dilemma for the opponent who proposes an enduring àtman that survives the process of reincarnation: Is the atman fundamentally the same, or different, from the skandhas? If the attman is the same as the skandhas, then, presumably, it is equivalent to one or more of the five skandhas. According to the Buddhist teaching, the five skandhas, are, by definition, momentary and impermanent. Hence, if the atman is associated with one or more of the five skandhas, then the atman must also be impermanent by nature. Thus, the first horn of the dilemma is meant to be unacceptable to the Brāhmanical antagonist who maintains the doctrine of the eternality of the atman. If, however, the atman is separate from the five skandhas, then, it would follow that the atman has no observable effects, as the five skandhas make up the entire gamut of the personality that is perceptible to the five senses. Thus, the second horn of the dilemma is intended to be equally unpalatable to the Brāhmanical antagonist who maintains that the existence of the atman can be inferred from its outward bodily activity and visible effects. In sum, Sanghabhadra's dilemma is meant to pose a thorny difficulty for the proponent of the attman as the locus of reincarnation. Both horns of the dilemma-namely, that the atman is equivalent to one or more of the skandhas, or, that the atman is separate from the skandhas-pose unwarranted consequences for the àtmavādin or proponent of the àtman.

In his Treatise Conforming to the Correct Logic of Abbidharma, Sanghabhadra adduces the example of the 'whirling firebrand' (Skt. alatta-cakra; Ch. xuan buolun 旋火輪) to illustrate the tenet of noself (Skt. anātman). ${ }^{84}$ The whirling firebrand consists of the moment

84 Nyāyanusāra śāstra, Apidamo shun zhengli lun, T no. 1562, 29: 50.622a19. Dhammajoti (Sarvāstivāda Abhidharma, 356) tracks the example of the optical illusion of a fire-wheel (alatta-cakra) resulting from the whirling firebrand to the 'Sautrāntikas, represented by Śrīlata'. 
to moment arising, abiding, and ceasing of flames that give the appearance of a continuous and enduring circle of fire. The image of the circle of fire is an optical illusion. Like the whirling firebrand, the enduring àtman is an illusion.

\section{Conclusion}

This paper finds that Vasubandhu and Sanghabhadra, in their investigations into the survivability of life, death, the intermediate state, and reincarnation, deploy the Abhidharma theory of the samtana to conceptualize the continuity of a sentient being without relying on the existence of enduring self, soul, or attman. This study examines the Chinese translations by Xuanzang and his cohort, and the Sanskrit and Tibetan versions of the Treasury of the Abhidharma by Vasubandhu, and the two earliest commentaries on this text, the Abhidharma Treatise Conforming to the Correct Logic and the Treatise Clarifying Abbidharma Tenets, by Sanghabhadra.

Vasubandhu and Sanghabhadra conceptualize the survivability of a living entity in terms of the perseverance of samtanna. To the Abhidharma theorists, the samtāna is not an atman, purusa, or enduring self, but a dynamic flow of causally-related dharmas. Vasubandhu and Sanghabhadra contend that the fundamental units of existence in Abhidharma Buddhism, the dharmas, are constantly arising, abiding, and ceasing from one moment to the next. Although each dharma perishes, the causal efficacy and causal capacity imparted by one dharma to the next creates the samtana, the continuum of dharmas, that persists over time. Vasubandhu and Sanghabhadra hold that the samtanna links the momentary dharmas together in a continuous flow, thus enabling a living entity to persevere in the face of radical momentariness.

This study finds that Vasubandhu and Sanghabhadra remain deeply sensitive to the challenges posed by the rival Brāhmanical teachings on the survivability of death. The theory of the samtana as the bearer of the skandhas represents a reasoned response to the problem of survivability that maintains fidelity to the core Buddhist tenets of momentariness and no-self. The causal efficacies and causal 
capacities of each dharma enable the samtāna of a sentient being to survive the vagaries of the changing environments of the purvabhava, maranabhava, antaräbhava, and upapattibhava. The samtāna accounts for the continuous identity of a sentient being in a world of constant change.

A more detailed study of the Buddho-Brāhmanical polemics on the question of what constitutes the agent of karma and the locus of transmigration, preserved in Abhidharma corpora of Sanghabhadra and Vasubandhu remains a matter for further research. While attention has been given to a critique of Sānkhya and views of karma and transmigration found in the ninth chapter of the Treasury of Abhidharma by Vasubandhu, the contents of the Abhidharma corpus of Sanghabhadra remains unmined. The Chinese and Tibetan recensions of the Abhidharma masterworks of Sanghabhadra contain rich discussions of the fifth-century Buddhist anti-Brāhmaṇical polemics on karma and transmigration and are deserving of further examination.

\section{Bibliography}

\section{Abbreviations}

D Derge Tengyur Canon. (sDe dge bsTan 'gyur Canon). Electronic edition from the TBRC https://www.tbrc. org/ and AIBS http://databases.aibs.columbia.edu/. Preserved at the Faculty of Letters, University of Tokyo. Edited by Takasaki Jikidō 高崎直道, Yamaguchi Zuihō 山口瑞鳳, and Hakamaya Noriaki 袴谷憲昭, 1980. Tokyo: Sekai Seiten Kankō Kyōkai.

T Taishō shinshū daizōkyō 大正新脩大藏經. Edited by Takakusu Junjirō 高楠順次郎 and Watanabe Kaigyoku 渡邊海旭, ca. 1924-1932. 85 vols. Tōkyō: Taishō issaikyō kankōkai 大正一切經刊刻會. (CBETA version).

X Manji Shinsan Dai Nibon zokuzōkyō せ新纂大日本 續藏經. Edited by Kawamura Kōshō 河村考照, ca. 1975-1989. Printed by Kokusho kangyōkai 國書刊行 
會. Originally compiled by Nakano Tatsue 中野達慧, ca. 1905-1912. Kyōtō: Zōkyō shoin 藏經書院 (CBETA version).

\section{Primary Sources}

*Abhidharmakośa-vrtti sūtrānurūpā (Tib. Chos mngon pa mdzod kyi bstan bcos kyi tshig le'ur byas pa'i mam par bshad pa). Attributed to Sanghabhadra ('dun bzang) and/or Vinītabhadra ('dul bzang). Derge Tengyur Canon, Work no. 4091, vol. 141.

Abhidharmakośabhassya [Commentary on the Treasury of

Abhidharma] of Vasubandhu. Tibetan translation by Jinamitra.

Chos mngon pa'i mdzod kyi bshad pa. Derge Tengyur Canon,

Work no. 4090, vol. 140.

Apidamo da piposha lun 阿毘達磨大毘婆沙論 [Skt.

*Abhidharmamahāvibhāsáa śāstra; Treatise of the Great

Commentary on the Abhidharma]. 200 juan. Trans. Xuanzang

玄牀 (600?-664) between 656-659. T no. 1545, vol. 27.

Apidamo fazhi lun 阿毘達磨發智論 [Skt.

Abbidharmajūānaprasthāna śāstra; Abhidharma Treatise on the

Basis of Gnosis]. 20 juan. Trans. Xuanzang 玄牀 (600?-664) in

657. $T$ no. 1544, vol. 26.

Apidamo jushe lun 阿毘達磨俱舍論 [Abhidharma Storehouse

Treatise]. 30 juan. Trans. Xuanzang 玄壯 (600?-664) between

614 and 654. T no. 1558, vol. 29.

Apidamo shun zhengli lun 阿毘達磨順正理論 [Skt.

* Abhidharmanyānanusāra śāstra; Treatise Conforming to the

Correct Logic of Abhidharma]. 80 juan. By Sanghabhadra, trans.

Xuanzang 玄牀 (600?-664) in 654 C.E. T no. 1562, vol. 29.

Apidamo xianzong lun 阿毘達摩顯宗論 [Skt.

* Abhidharmakośaśāstrakārikāvibhāsya,

* Abbidharmasamayapradīpikà śāstra, or

* Abhidharmapițakaprakaranaśásana sástra; Clarification of

Abhidharma Tenets]. 40 juan. By Sanghabhadra (Zhongxian 眾

賢; of the 5th c.), trans. Xuanzang 玄牀 (600?-664) between 651

and 652 C.E. $T$ no. 1563 , vol. 29.

Apitan ganluwei lun 阿毘昙甘露味論 [Skt. * Abhidharmāmrta- 
rasa sástra, *Abhidharmāmrta śāstra; Treatise Containing the Essential Juice of the Abhidharma]. 2 juan. By an unknown translator. Tno. 1553, vol. 28.

Apitan xin lun 阿毗昙心論 [Skt. *Abhidharmasāra, *Abbidharmabrdaya śāstra; Abhidharma Heart Treatise]. 11 juan. Translated by Samghadeva (Senqietipo 僧伽提婆; of 4th c.) and Lushan Huiyuan 盧山慧遠 (334-416) in 391. T no. 1544, vol. 26.

Dasheng guang bailun shilun 大乘廣百論釋論 [Skt. ${ }^{*}$ Catubśatakavrtti; Commentary on the Dasheng Guang bailun 大乘廣百 論 (Mahāyāna-Vaipulya One Hundred Treatise)]. 10 juan. By Dharmapāla, trans. Xuanzang 玄牀 $(600 ?-664)$ in 650. T no. 1571, vol. 30.

Pañcaskandhaka of Vasubandhu and Pañcaskandhakavibhāsa of Sthiramati. For critical edition of the former see Steinkellner, E., Li, Xuezhu (eds.), 2012; for the Vibhāṣa, see Kramer J (ed.), 2014: Sanskrit Texts from the Tibetan Autonomous Region, published by China Tibetology Center and Austrian Academy of Sciences.

Sāmkhya-kārikēa. Edited by Sharma Dutt. Poona (Puna): The Oriental Book Agency, 1933.

Sphutārthā Abhidharmakośa-Vyākhyā of Yaśomitra. Edited by Swami Dwarikadas Shastri. Varanasi: Bauddha Bharati Series-5, 1970. Tibetan translation by Viśuddhasiṃha, et al. Derge Work No. 4092, vol. 142.

Yibu zonglun lun 異部宗輪論 [Skt. *Samayabbedôparacanacakra śástra of Vasumitra (Tib. dbyig bshes; Ch. Shiyou 世友); Treatise on the Wheel of Different Tenets]. 1 juan. Trans. Xuanzang 玄焋 (600?-664) in 662; $T$ no. 2031, vol. 49; Tibetan translation by T. Dharmakara and Bzan-skyon, Gzbung lugs kyi bye brag bkod pa'i 'khor lo, Derge Work no. 4138, vol. 167.

Za apitan xin lun 雜阿毘曇心論 [Skt. ${ }^{*}$ Samyuktâbhidharmabrdaya śástra; Heart of Scholasticism with Miscellaneous Additions]. 11 juan. Trans. Samghavarman (Sengqiebamo 僧伽跋摩; active between 434-442), et al. in 434. T no. 1552, vol. 28. 


\section{Secondary Sources}

Bareau, A. Les sectes bouddhiques du petit vébicule [Buddhist sects of the small vehicle]. Saïgon: École française d'Extrême-Orient, 1955.

_- 'Trois traités sur les sectes bouddhiques attribues a Vasumitra, Bhavya et Vinītadeva' [Three treatises on the Buddhist sects attributed to Vasumitra, Bhavya and Vinītadeva]. Journal Asiatique [Asiatic Journal] 242 (1954): 229-66.

Bhikku Anālayo. 'Rebirth and the Gandhabba'.

Mahachulalongkornrajavidyalaya University Journal of Buddhist Studies 1 (2008): 91-105.

Bronkhorst, J. Buddhism in the Shadow of Brabmanism. Leiden: Brill, 2011.

Bryant, E.F. 'Agency in Sāṃkhya and Yoga: The Unchangeability of the Eternal'. In Free Will, Agency, and Selfhood in Indian Philosophy, edited by Matthew Dasti and Edwin Bryant, 16-40. New York: Oxford University Press, 2013.

Châu, T. The Literature of the Personalists of Early Buddhism, Vol. 39. Delhi: Motilal Banarsidass Publisher, 1999.

Cox, Collett. Disputed Dharmas: Early Buddhist Theories on Existence. Seattle: University of Washington Press, 1997.

Cuevas, B. J. 'Predecessors and Prototypes: Towards a Conceptual History of the Buddhist Antaräbhava'. Numen 43, no. 3 (1996): 263-302.

Demiéville, P. 'L’origine des sectes bouddhiques d'apres Paramārtha' [The origin of the Buddhist sects according to Paramārtha]. Mélanges chinois et bouddhiques [Miscellany of Chinese and Buddhist Studies] 1 (1931-1932): 15-62.

_. 'Les versions chinoises du Milindapañha' [Chinese version of the Milindapañba]. Bulletin de l'École française d'ExtrêmeOrient [Bulletin of the French School of Asian Studies] 24 (1924): 1-253.

Dhammajoti, K.L. Sarvāstivāda Abhidharma. Hong Kong: Centre of Buddhist Studies, 2007.

Frauwallner, Erich. Studies in Abhidharma Literature and the Origins of Buddhist Philosophical Systems: Translated from the German 
by Sophie Francis Kidd as Translator and under the Supervision of Ernst Steinkellner as Editor. New York : SUNY Press, 1995.

Garfield, J. L. Engaging Buddhism: Why It Matters to Philosophy.

Oxford: Oxford University Press, 2014.

Gethin, Rupert. 'The Five Khandhas: Their Treatment in the

Nikāyas and Early Abhidharma'. Journal of Indian Philosophy 14, no. 1 (1986): 35-53.

Hirakawa Akira 平川彰. Buddhist Chinese-Sanskrit Dictionary.

Tokyo: Reiyukai 靈友會, 1997.

—. Index to the Abhidharmakośabhāsya 阿毘達磨俱舎論索引. 3

vols. Tokyo: Daizō Shuppan 大藏出版, 1977.

Ikeda, R. 'On the Functions of Antarābhava'. Indogaku Bukkyōgaku

Kenkyū 印度學佛教學研究 [Journal of Indian and Buddhist

Studies] 39, no. 2 (1991): 926-922.

Kritzer, R. 'An Atman by Any Other Name: Two Non-Buddhist

Parallels to Antarābhava'. Indogaku Bukkyōgaku Kenkyū 印度學

佛教學研究 [Journal of Indian and Buddhist Studies] 47, no. 1 (1998): 506-500.

—. 'R üpa and the Antaräbhava'. Journal of Indian Philosophy 28 (2000): 235-72.

—. 'Semen, Blood, and the Intermediate Existence'. Indogaku Bukkyogaku Kenkyū 印度學佛教學研究 [Journal of Indian and Buddhist Studies] 46, no. 2 (1998): 1031-1025.

La Vallée Poussin, Louis de. L'Abbidharmakośa de Vasubandbu [The Abhidharmakośa by Vasubandhu]. Paris: Paul Geutner, 1926.

Lamotte, Étienne. 'Problemes concernant les textes canoniques Mineurs' [Problems with Minor Canonical Texts].Journal Asiatique [Asiatic Journal] 244 ,no. 3 (1956): 249-64.

_. La traité de la grande vertu de sagesse (Mahāprajñāpāramitā Śàstra) [The Treatise on the Great Virtue of Wisdom (Mahāprajñāpāramitā Śástra)]. Louvain: Institut Orientaliste de Louvain, 1944.

Lusthaus, D. Buddhist Phenomenology: A Philosophical Investigation of Yogācāra Buddhism and the Ch'eng Wei-shih Lun. New York: Routledge Press, 2014.

Mahony, William K. 'Concepts of the Soul in Indian Religions'. In 
Death, Afterlife, and the Soul, edited by Lawrence E. Sullivan, 189-98. New York: Macmillan Publishers, 1987.

Masuda, J. Origin and Doctrines of Early Indian Buddhist Schools: A Translation of the Hsüan-Chwang Version of Vasumitra's Treatise. Leipzig: Verlag der Asia Major, 1925.

Matsushima, H. 'Sanghabhadra on Karma and Momentariness'. Indogaku Bukkyogaku Kenkyū 印度學佛教學研究 [Journal of Indian and Buddhist Studies] 58, no. 3 (2010): 1159-63.

Mejor, Marek. Vasubandhu's Abhidharmakosa and the Commentaries Preserved in the Tanjur. Stuttgart: Franz Steiner Verlag Stuttgart, 1991.

_ _ 'Vasubandhu's Abbidharmakośa in non-Buddhist philosophical treatises'. Buddhist Studies 8 (2008): 119-50.

Nagasawa, J. 'A Problem Concerning the Mirror Simile Found in the Samdhinirmocana-sütra'. Indogaku Bukkyōgaku Kenkyū 印度 學佛教學研究 [Journal of Indian and Buddhist Studies] 7, no. 2 (1959): 647-50.

Nattier, J. J. 'Mahāsāṃghika origins: The Beginnings of Buddhist Sectarianism'. History of Religions 16 (1977): 237-72.

Oberlies, Thomas. 'Der Gandharva und die drei Tage Währende "Quarantäne" [The Gandharva and the three-day quarantine]. Indo-Iranian Journal 48, no. 1-2 (2005): 97-109.

Pradhan, Pralhad, ed. Abbidharmakośabhāsya of Vasubandhu. Patnam: Jayasawal Research Institute, 1967.

Pruden, L. Abhidharmakośabhāyam, English Translation of Poussin, Louis de la Vallée. 1923-1931/1980. L'Abbidharmakośa de Vasubandhu. 6 vols. Bruxelles: Institut Belge des Hautes Études Chinoises, 1971. Berkeley: Asian Humanities Press, 1988. Radich, Michael. 'Ideas about Consciousness in Fifth and Sixth Century Chinese Buddhist Debates on the Survival of Death by the Spirit, and the Chinese Background to *Amalavijñāna'. In A Distant Mirror: Articulating Indic Ideas in Sixth and Seventh Century Chinese Buddhism, edited by Lin Chen-kuo and Michael Radich, 471-512. Hamburg: Hamburg University Press, 2014.

Sanderson, Alexis. 'The Sarvāstivāda and Its Critics: Anātmavāda and the Theory of Karma'. In Buddhism into the Year 2000: 
International Conference Proceedings, 33-48. Bangkok:

Dhammakaya Foundation, 1994.

Schmithausen, Lambert. Plants in Early Buddhism and the Far

Eastern Idea of the Buddha-Nature of Grasses and Trees.

Lumbini: Lumbini International Research Institute, 2009.

- The Problem of the Sentience of Plants in Earliest Buddhism.

Studia Philologica, monograph series VI. Tokyo: The

International Institute for Buddhist Studies, 1991.

Siderits, Mark. Buddhism as Philosophy. Indianapolis: Ashgate, 2007.

Skilling, P. 'Rehabilitating the Pudgalavādins: The Monastic Culture

of the Vātsīputrīya-Saṃmitìya School'. Journal of Buddhist

Studies 8 (2016): 1-55.

Stcherbatsky, Theodore. 'The Soul Theory of the Buddhists'.

Bulletin de l'Academie des Sciences de Russie [Bulletin of the

Russian Academy of Sciences] (1919): 823-958.

Stone, J. Right Thoughts at the Last Moment: Buddhism and

Deathbed Practices in Early Medieval Japan. Honolulu: Kuroda

Institute, University of Hawai'i Press, 2016.

Teramoto, E. 寺本婉雅. Zō-Kan-Wa sanyaku taikō I bu shū rin ron 蔵漢和三訳対校異部宗輪論 [Tibetan-Chinese-Japanese Parallel Edition of Samayabhedoparacana-cakra śastra]. Tokyo:

Kokusho kankōkai 國書刊行會, 1974.

Tsukamoto, K. The Cycle of the Formation of the Schismatic Doctrines. Berkeley: Numata Center for Buddhist Translation and Research, 2004.

von Rospatt, A. The Buddhist Doctrine of Momentariness: A Survey of the Origins and Early Phase of this Doctrine up to Vasubandhu. Alt-und nue-indische Studien [Ancient and New Indian Studies] 47. Stuttgart: Franz Steiner Verlag, 1995.

Watson, Alex. 'Bhațta Rāmakaṇṭha's Elaboration of Self-Awareness (svasamvedana), and How It Differs from Dharmakīrti's Exposition of the Concept'. Journal of Indian Philosophy 38, no. 3 (2010): 297-321.

_ _ 'The Self as a Dynamic Constant: Rāmakanțtha's middle ground between a Naiyāyika eternal self-substance and a Buddhist stream of consciousness-moments'. Journal of Indian Philosophy 42, no. 1 (2014): 173-93. 
- The Self's Awareness of Itself: Bhatța Rämakantha's Arguments against the Buddhist Doctrine of No-Self. Wien: Publications of the De Nobili Research Library, 2006. Werner, Karel. 'Book Review: The Problem of the Sentience of Plants in Earliest Buddhism by Lambert Schmithausen (Tokyo, The International Institute for Buddhist Studies, 1991)'. Journal of the Royal Asiatic Society 9, no. 1 (1999): 183-84.

Yao Zhihua 姚治華. Yibu zonglun lun 異部宗輪論 [Skt. Samayabhedoparacana cakra; Treatise of the Wheel of the Different Divisions of the Tenets]. Gaoxiong: Foguang chubanshe 佛光出 版社, 1996.

Yinshun 印順. Shuo yiqie youbu weizhu de lunshu yu lunshi zhi yanjiu 說一切有部爲主的論書與論師之研究 [Research on the Sarvāstivāda Abhidharma Treatises and Sarvāstivādin Masters]. Taipei: Zhengwen chubanshe 正聞出版社, 1978. Zhongguan lun song jiangji 中觀論頌講記 [Lecture Notes on the Stanzas of the Mülamadhyamakakārikā]. Taipei: Zhengwen chubanshe 正聞出版社, 1981. 